\title{
Ethiopia's Justice System Reform at Crossroads: \\ Impediments relating to Institutional Continuity, Ethnic Politics and the Land Regime
}

\section{Abstract}

Elias N. Stebek *

Ethiopia's Justice System Reform Program has not achieved the pledges that were promised since 2002. One of the sources for the impediments was 'revolutionary democracy' because its 'democratic' limb represented the pursuits of justice system reform while its 'revolutionary' limb caused impediments to the reform. This involves various manifestations of 'revolutionary democracy' which include institutional discontinuity, ethnic politics and reluctance to land reform. Disruptions owing to periodic changes in institutional structures (and mandates) adversely affect institutional memory and continuity in Ethiopia's justice system reform. The second impediment relates to problems in law and order owing to the risky experiment in ethnic politics that has nurtured ethnic radicalism and hostilities along linguistic lines thereby creating pressures on the justice sector. It has also impeded attainments in the first two dimensions of good governance, (i.e. voice and accountability) because genuine voice of citizens envisages rational choice as opposed to ethnicity. The third trap which is among the manifestations of 'revolutionary democracy' involves rigidity against reforming Ethiopia's land law which has handcuffed broadbased economic performance thereby impairing the resource base of all reform pursuits (including justice system reform). The way forward thus envisages not only addressing the external manifestations of the problems in the justice system, but also requires directly addressing the root causes of the impediments.

\section{Key terms}

Justice system reform · Good governance - Nation building · Land tenure security; Ethnic politics · Ethiopia

DOI http://dx.doi.org/10.4314/mlr.v12i2.2

This article is licensed under a Creative Commons Attribution-NonCommercialNoDerivs (CC BY-NC-

\footnotetext{
* Elias N. Stebek (LL.B, LL.M, PhD), Associate Professor, St. Mary’s University, School of Graduate Studies. Email: <elstebek@gmail.com>

Some sections of the initial version of this article were part of an unpublished first draft of a research paper (titled: “Ethiopia's Justice System Reform Pledges, Gaps and the Way Forward") submitted to Ethiopian Lawyers Association, on September 16, 2018.
}

Frequently used Acronyms:

JLSRI: Justice and Legal System Research Institute

JLRTI: Justice and Legal Research and Training Institute 


\section{Introduction}

The concept of 'Revolutionary Democracy' is affiliated to Vladimir I. Lenin's 'New Democratic Revolution' (NDR). For Lenin, NDR meant an interim phase toward socialism and communism. According to Lenin, the victory of "a revolutionary-democratic dictatorship of the proletariat and the peasantry" will enable the communist party "to rouse Europe, and the socialist proletariat of Europe". ${ }^{1}$ On the contrary, 'Revolutionary Democracy' in post-1991 Ethiopia embodied contradictory meanings, because it claimed to represent 'economic and political liberalization' in official discourse, while it was clearly within the ambit of Marxist-Leninist thinking in political party operations and party-state relations.

It was in the midst of such inherent contradiction in the concept of 'revolutionary democracy' that achievements were attained in the formulation of the 2002 Justice System Reform Program (JSRP) and the 2005 Comprehensive Justice System Reform Program (CJSRP). ${ }^{2}$ The 'democratic' limb of revolutionary democracy facilitated the formulation of the 2002 JSRP and the 2005 Comprehensive Justice System Reform Program, and on the contrary, its 'revolutionary' limb (caused by the Marxist heritage of the political leadership) was incongruent with most parts of JSRP's and CJSRP's recommendations. The cutbacks in the pace of justice system reform were apparent in 2005/2006 (immediately after the 2005 elections) and from 2007 onward under pledges of 'democratic developmental statehood'.

There was indeed optimism that the attention given to justice sector reform during the formulation of the program would be sustained in its implementation phases as well. However, sixteen years after the take-off towards Justice System Reform Programme in $2002^{3}$, Ethiopia's justice sector has regressed ${ }^{4}$, and this can be verified by the facts that were officially admitted (after the 2018 political

${ }^{1}$ Vladimir Ilyich Lenin (1905), Two Tactics of Social-Democracy in the Democratic Revolution, Collected Works, 1962, Vol. 9, (Translation: Abraham Fineburg and Julius Katzer), pp. 15-140, Section 10: "Revolutionary Communes" and the RevolutionaryDemocratic Dictatorship of the Proletariat and the Peasantry.

${ }^{2}$ The Comprehensive Justice System Reform Program Baseline Study Report, Ministry of Capacity Building, Justice System Reform Program Office, February 2005.

${ }^{3}$ Ministry of Capacity Building, Justice System Reform in Ethiopia: Proceedings of the Workshop on Ethiopia's Justice System Reform, Africa Hall, 7-8 May 2002.

${ }^{4}$ For details on the regression in the pace of justice sector reform programmes see two articles by this author published in Mizan Law Review, Volume 9, No. 2, titled "Judicial Reform Pursuits in Ethiopia, 2002-2015: Steady Concrete Achievements - versus Promise Fatigue" (pp. 215-257), http://dx.doi.org/10.4314/mlr.v9i2.1 and "Legal Sector Reform Pursuits in Ethiopia: Gaps in Grassroots Empowerment" (pp. 258300), http://dx.doi.org/10.4314/mlr.v9i2.2 
reforms) regarding the unconstitutional acts of various law enforcement institutions. Steadily declining public trust in the justice sector (i.e., the legal and judicial sectors) renders the discourse on justice sector reform as relevant and expedient today as it was in 2002. This article focuses on certain themes that are relevant in the way forward towards the reinvigoration of the 2002 and 2005 aspirations which, inter alia, require dealing with impediments of reform.

Section 1 presents an overview of institutional discontinuity in Ethiopia's justice sector during the last decades, and Section 2 discusses the current pursuits in law reform and the resumption of justice system reform projects. The third and fourth sections deal with the problems of institutional discontinuity in the coordination of the justice system reform program and in relation to trends of scrapping codes of law in the name of revision. Sections 5 and 6 respectively highlight the nexus between good governance and justice sector reform, and the tension between good governance and ethnic politics. Based on these themes, Sections 7 to 10 highlight four challenges in justice sector effectiveness in the context of ethnic politics. The themes are: law compliant citizenship, peace and order in the context of diversity, the tension between multi-ethnic civic identity and Article 39 of the FDRE Constitution, and the constitutionality debate regarding the emblem on the Ethiopian flag. Sections 11 and 12 respectively deal with the need for land reform and normative gate keeping against predatory statehood.

\section{Overview of Institutional Discontinuity in Ethiopia's Post- 1931 Laws and Justice Sector}

Ethiopia's 1931 Constitution was a significant achievement in lawmaking. The reformers of the period (who were regarded as Japanizers) sought modernization and progress. ${ }^{5}$ Another significant landmark in legal development was the Negarit Gazeta which began to be promulgated in March 1942. In spite of its slow pace, justice sector institution building (including the legal regime) continued, and the attainments included the 1955 Revised Constitution. A major achievement in this regard relates to the codification of six codes of law -from 1957 to 1965- and the establishment of Faculty of Law at Haile Selassie I University (currently Addis Ababa University) in 1963. These achievements resulted from the modernization thinking of the period and the belief in a legal system's instrumental function in development.

The 1960 Civil Code and Commercial Code had envisaged facilitating the modernization of Ethiopia through the path undergone by the Global North

\footnotetext{
${ }^{5}$ See, for example, Bahru Zewde (2002). Pioneers of Change in Ethiopia: The Reformist Intellectuals of the Early Twentieth Century (J. Currey Publisher).
} 
through reception of their institutions including laws. However, legal institutions cannot be regarded as mere results of political will. Nor can the law be regarded as a stand-alone toolkit for social engineering. Indeed, progress in the legal regime and justice sector institutions has a bi-directional relationship with the corresponding social and economic realities that render a rational legal system and justice sector expedient, and at the same time facilitate its development, implementation, outcomes and impact.

Unfortunately, however, Ethiopia's pace of nation-building and legal development (in 1942-1974) failed to catch up with unfolding realities on various fronts, which include: (i) land reform, (ii) constitutional reforms that, inter alia ensure equality in religion and ethnic identity, (iii) reform towards constitutional monarchy, and (iv) the accommodation of federalism in Eritrea in accordance with the UN General Assembly's Resolution, rendered in $1950 .{ }^{6}$

In addition to these domestic problems, the global economic system brought about widening gaps in balance of trade in developing countries accompanied by the global oil crisis during the early 1970s. As the regime failed to address the domestic challenges and the effects of the 1973/74 global oil crisis, promises of reform in Mid-1974 including a draft constitution toward constitutional monarchy ${ }^{7}$ seemed to be too-little-too-late after the 1974 revolution.

There were indeed lost opportunities in land reform, nation-state building and institutional development (including the justice sector) which include the absolute monarchy's failure to reform itself during the 1960s and early 1970s. There was a similar failure to learn from models of pragmatic reform (such as the South Korean path) that could have been adopted upon the advent of the Dergue to power in September 1974. Such options could have been conducive to incremental and steady institutional reforms (including the justice sector) thereby facilitating institutional continuity in the organic improvement of lawmaking, court systems, law enforcement, law practice and legal education.

In contrast to the modernization theory which was reflected in the legal development pursuits of the $1960 \mathrm{~s}$, communism -that was tailored to the $19^{\text {th }}$ century realities of England, France and Germany- informed policies in Ethiopia from 1975 until the late 1980s. Analogous to the attempts to revise the 1955 Constitution toward constitutional monarchy in 1974, the economic reform pledges of the late 1980s were eleventh-hour attempts. It is to be recalled that a request for mixed economy by Col. Atnafu Ababte was unduly suppressed in September-October 1977. Even worse, the Dergue was too rigid to consider a political solution (such as federation) to Eritrea.

\footnotetext{
${ }^{6}$ UN General Assembly's Resolution 390-A(V), 2 December 1950.

${ }^{7}$ See, for example, New York Times, 7 August 1974, p. 38. "A New Constitution offered in Ethiopia”, citing AP, August 6, 1974.
} 
Even though the land reform of $1975^{\circ}$ was a positive achievement, its extremely radical content was incongruent with Marx's views (whose ideology was pledged to be pursued), because Karl Marx (1818-1883) did not envisage nationalization of the means of production before the attainment of the capitalist mode of production. According to Marx, socialized production and private appropriation reach at a stage of an irreconcilable contradiction under an advanced level of capitalism. He argued that "scattered private property arising from individual labour" is transformed "into capitalist private property" and he considered this as "the expropriation of the mass of the people by a few usurpers". 9 Based on this premise, Marx envisaged "the transformation of capitalistic private property, already practically resting on socialized production, into socialized property". ${ }^{10}$ For Marx, this constitutes "the expropriation of a few usurpers by the mass of the people". 11

At hindsight, it can be observed that Ethiopia's 1975 land reform could have benefited from pragmatism and reason -as was the case in South Korea- and this would have enabled the appropriate balance between equity (distributive justice) and economic efficiency. Ethiopia's 1975 land reform solely focused on distributive justice, and this has ultimately brought about land fragmentation and shared impoverishment. Farm size steadily declined owing to Ethiopia's rising population and the slow pace in the transition to manufacturing-led economy. According to a 2015 study by FAO, Ethiopia's "average small farm size is 0.9 hectares" ${ }^{\prime 12}$, and the study indicates the decline in average small farm size "from 1.43 hectares in 1977 to 1.03 in 2000 ". 13

For example, the nationalization of modern farms (owned and managed by professionals and entrepreneurs) in 1975 merely led to state farms that were largely bankrupt and subsidized. Moreover, exceptions could have been made to room rentals in urban house compounds as long as the parcel size did not exceed the maximum (i.e. 500 sq. meters) that was allowed in the 1975 Urban Land and Extra Houses Proclamation. ${ }^{14}$ However, the rush of the Marxists -during the

\footnotetext{
${ }^{8}$ Public Ownership of Rural Lands Proclamation No. 31/1975.

${ }^{9}$ Karl Marx (1867), (English Translation, 1887, by Samuel Moore \& Edward Aveling), Capital: A Critique of Political Economy, Volume 1, Book One: The Process of Production of Capital, Chapter 32, "Historical Tendency of Capitalist Accumulation", Progress Publishers, Moscow (1954), p. 715.

${ }^{10}$ Ibid.

${ }^{11}$ Ibid.

${ }^{12}$ George Rapsomanikis (2015), The economic lives of smallholder farmers: An analysis based on household data from nine countries (Food and Agricultural Organization of the United Nations, Rome), p. 5

${ }^{13}$ Ibid.

${ }^{14}$ Government Ownership of Urban Lands and Extra Houses Proclamation No. 47/1975.
} 
period- was to avoid the tag of 'revisionism'. Thus, pragmatic options of land reform (such as abolition of tenancy and ensuring tenure security to smallholder farmers, compensation to former landowners with exceptions stated by law, etc) would not have been acceptable to the Ethiopian left. An ideology that emerged as an anti-thesis against a fully developed capitalist mode of production was imported dogmatically to a predominantly agrarian Ethiopia of the Mid 1970s.

With regard to the judiciary (in 1974-1991), there were extra-judicial interventions such as military tribunals. But these interventions did not involve simulations thereby leaving the judiciary to operate -on its own-in commercial, civil, tax and non-political criminal cases. Even though ordinary courts were recognized as the only judicial organs under the 1987 People's Democratic Republic Ethiopia (PDRE) Constitution, a military tribunal was established against the leaders of the coup that was attempted in May 1989. The executive was thus resorting to such tribunals whenever it needed intervention, and it did not need a façade of 'show trials' through the ordinary courts.

However, special tribunals outside ordinary courts are not formally possible after 1991 owing to the pledges of constitutional democracy and separation of powers. During this period, executive intervention in judicial matters could only be done through the ordinary courts which eventually became a modus operandi in many benches. Eventually, the level of political intervention (in 2017, for example) included the act of gathering judges and court staff for sessions that were known as 'renewal' and 'deep renewal' ('tehadiso' and 'tilq tehadiso'). Although courts are declared to be independent under Article 79 of the FDRE Constitution, there was apparent intervention of the executive (and the political leadership) because 'revolutionary democracy' influenced the policy framework (including the justice system).

\section{Current Pursuits in Law Reform and Justice System Reform Projects}

\subsection{Pursuits of law reform}

There is an initiative toward law reforms by the Federal Attorney General. To this end, it had organized a workshop conducted on June 6, 2018. As noted during a presentation at the workshop, there are problems and limitations in the justice sector, ${ }^{15}$ which include:

a) deterioration in the quality of laws,

b) absence of a forum that facilitates consistent and meaningful consultation,

c) absence of a scheme that can be used to analyze the extent to which laws are just, effective and viable,

\footnotetext{
${ }^{15}$ Dr. Mulugeta Mengist, Presentation at the Consultative Workshop on Problems in Ethiopia's Justice conducted at Capital Hotel, June 6, 2018.
} 
d) the erroneous view which unduly strives to discard laws merely because they

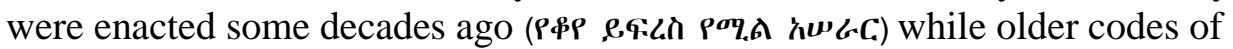
laws in Europe are still operative, and

e) problems related to independence and effectiveness.

According to Dr. Mulugeta, the problems in the justice sector are, inter alia, attributable to "abrupt switch to different tracks (such as BPR) analogous to

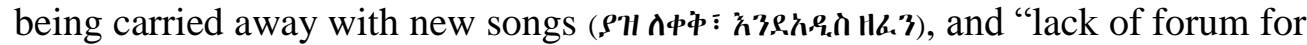
consultation, discourse and analysis". He also noted the "gaps in the institutionalization of achievements and performance, and gaps in institutional memory." Moreover he indicated other factors such as the historical context and "the internal operations and structures of justice sector institutions." 16

The workshop aimed at facilitating discussion on issues of concern in Ethiopia's justice sector. As Attorney General Birhanu Tsegaye stated, an Advisory Council has been established, and it is entrusted with the task of presenting "proposals on certain laws that are believed to narrow the political space in order for the government to make amendments" which include the antiterrorism and the charities and societies proclamations. "The Council is conducting studies to make sure whether the existing laws [comply] with the Constitution" with a view to "improving the justice system, ensuring the rights of citizens and broadening the political space". ${ }^{18}$ The Council's Chairperson, Professor Tilahun Teshome, has likewise expressed the need for justice sector reform in order to ensure rule of law, peace and development. ${ }^{19}$

Dr. Gedion Timothewos, Coordinator of the Research Team on the Antiterrorism Proclamation, stated that the Legal and Justice Affairs Advisory Council has adopted a roadmap for three years, based on research. He also pointed out that in addition to the workshops and panel discussions, "platforms will be created to incorporate the views and ideas of political party leaders, journalists, prosecutors and lawyers". ${ }^{20}$

\subsection{The JLRTI study towards resuming justice system reform projects}

Justice and Legal Research and Training Institute (JLRTI) is expected to resume the projects under the Justice System Reform Program based on its mandate under Proclamation No. 1071/2018. The Federal Supreme Court, Federal

\footnotetext{
${ }^{16}$ Ibid.

${ }^{17}$ Ethiopian News Agency, June 29, 2018.

${ }^{18}$ Ibid.

${ }^{19}$ Professor Tilahun Teshome, Addis Ababa University, School of Law, Fana Broadcasting, August 18, 2018.

${ }^{20}$ Ethiopian News Agency, August 18, 2018. Dr. Gedion Timothewos, Addis Ababa University, School of Law.
} 
Attorney General, Justice and Legal Research and Training Institute, and Higher Education Strategy Center have conducted a joint study with regard to the gaps in the pace and attainments of the justice system reform sub-programs that were formulated under the 2005 Justice System Reform Program. These studies were compiled under the auspices of Justice and Legal Research and Training Institute (JLRTI) and were presented as a joint study by presenters from the respective justice sector institutions at the Joined-up Justice Forum workshop in Adama on August 28, 2018. ${ }^{21}$

The introduction of the joint study ${ }^{22}$ by justice sector institutions (hereinafter referred to as the JLRTI Study) recalls the level of attention that was given to the Justice System Reform Program during the initial years, and it highlights the factors that contributed to the decline in the pace of its effective implementation. The study indicates the transfer of the coordination task [from the Justice System Reform Program Office at the Ministry of Capacity Building] to Justice and Legal System Research Institute (JLSRI) in 2005/2006. It appreciates the achievements (during the coordination by JLSRI) in the field of legal education reform which includes the development and implementation of a new LLB Programme curriculum and academic staff capacity development pursuits. However, it notes that the attainments in the judicial and law enforcement subprograms of the 2005 Comprehensive Justice System Reform Program were inadequate after the coordination function was transferred to JLSRI.

According to the study, there was further regression in the Justice System Reform Program after JLSRI ceased to coordinate the program due to the decision of functional rearrangements that led to the fragmented implementation of the sub-programs [since 2010/11]. The regression in justice system reform program continued further because it was ultimately subsumed under general themes such as good governance after the task of coordination was transferred to the Ministry of Public Service and Human Resources Development. ${ }^{23}$

Part Four of the study deals with analysis and findings that relate to the three sub-programs under Ethiopia's justice sector reform (i.e. sub-programs for

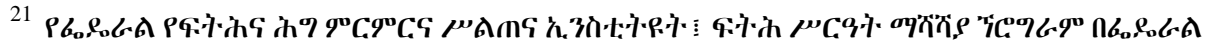

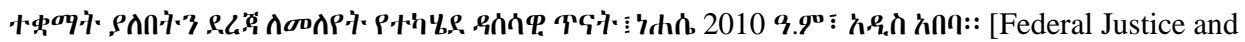
Legal Research and Training Institute, Assessment of the Status of Justice System Reform Program in Federal Institutions, August 2018, Addis Ababa]

${ }^{22}$ Id., pp. 4, 5.

23

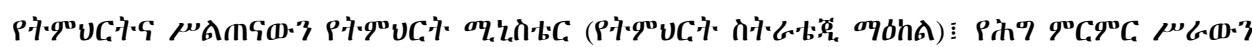

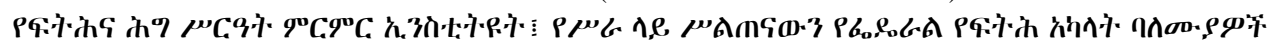

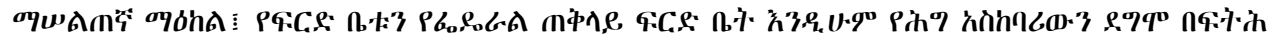

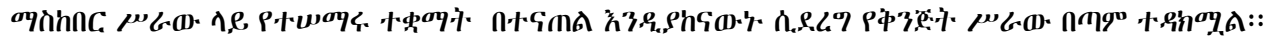

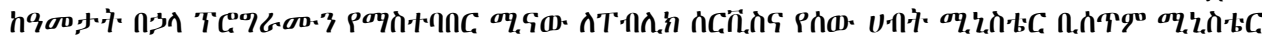

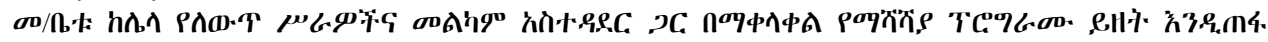

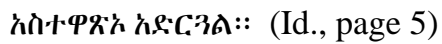


judicial reform, law enforcement reform and legal education). It discusses the goals that were attained (during the period between 2003 to 2010 Ethiopian Calendar, i.e. 2010/11 to 2017/18) among the planned activities under 54 projects, ${ }^{24}$ the activities that were not performed under each sub-program, the challenges encountered, the tasks that have become regular tasks, and good practices.

The fifth part states the findings, conclusions and recommendations of the study. The gaps stated in the findings include the following:

- there are "problems and public concerns in service provision and good governance with regard to the registrar [and] judicial decisions ...", ${ }^{25}$

- the measure of subsuming justice system reform program under the Ministry of Public Service was not effective ${ }^{26}$

- draft laws are not mostly based on research; there is failure to comply with the procedures of legislative drafting; and the quality of various legislative drafts is low; ${ }^{27}$

- there are gaps in the quality of charges submitted to courts and in the levels of skills and diligence with regard to public prosecution services;

- "there were violations committed by prison warders and administrative office holders in the treatment and respect of the human rights of prisoners;" 28

- the problems in law schools include admission of students with low national exam results, shortage of law school teaching staff, inadequate networking between justice sector institutions and legal education, absence of pedagogy training to newly recruited law teachers, and shortage of teaching materials; ${ }^{29}$

- there is the problem of "opening of law schools in large numbers without due attention to standards thereby resulting in a steady decline in the quality of legal education. ${ }^{30}$

24

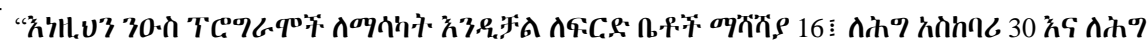
\$90

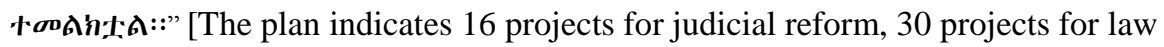
enforcement reform 8 projects for legal education reform, i.e. a total of 54 projects]. Id., page 25 .

25 Id., page 136.

${ }^{26}$ Id. p. 140.

${ }^{27}$ Id., p. 141.

${ }^{28}$ Id. p. 144.

${ }^{29}$ Id. pp. 146-147.

${ }^{30}$ Id. p. 147.

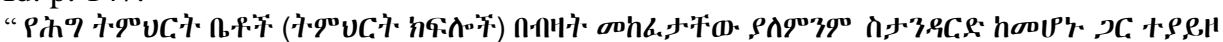

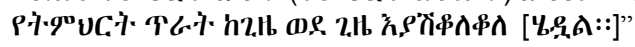


The study notes the gaps in the institutional framework towards coordination and harmonization of justice sector reform that have adversely affected the achievements in the sector:

"Most [justice sector] institutions do not have offices or professionals in charge of justice system reform activities. Justice and Legal Research and Training Institute does not have an office with a professional staff that is specifically designated to conduct the justice system reform activities at required level. There was no institution that follows up, evaluates and supports justice sector institutions in the course of their plans and achievements [in their respective sub-programs]. While most of the project activities were being conducted as ordinary functions, some projects are not performed due to shortages in finance and manpower". ${ }^{31}$

The study further states recommendations for the various entities that are in charge of the sub-programs on judicial reform, law enforcement, and legal education. The recommendations of the JLRTI Study with regard to the judicial reform sub-program ${ }^{32}$ include the following:

a) due attention to the level of satisfaction of judicial service recipients, stakeholders and lawyers and to public trust, in addition to the focus courts have hitherto given to internal operations and institutional arrangements;

b) identify barriers that impede the enhancement of public satisfaction and trust;

c) ensure that statements of claims/charges, statements of defence, memoranda of appeal, etc., fulfil the requirements under the laws of procedure (both in content and form);

d) the independence of courts accompanied by neutrality and accountability;

e) ensuring the independence and neutrality of courts including their empowerment to prepare their annual budget and to submit it to the House of Peoples Representatives;

f) executing a system (beyond the exchange of reports) that facilitates in-depth follow up, analysis and evaluation of implementation in the judicial reform sub-program;

g) staff engagement and motivation by going beyond the minor improvements in operations, service provision and human resource development that have accrued from previous instruments;

h) enhancing the consistency and predictability of sentences in criminal cases;

i) provision of residential facilities to judges, implementation of the draft salary scale for judges, and facilitating their academic development;

j) pursuance of the projects of reform that are underway;

\footnotetext{
${ }^{31}$ Id. p. 145.

${ }^{32}$ Id. pp. $148-150$.
} 
k) strengthening the activities that were part of the judicial reform sub-program and that have now been classified as ordinary activities; and

1) initiating new projects that bring about judicial reform through tools that facilitate concrete and visible performance towards achieving the projects of judicial reform.

The recommendations in the JLRTI study with regard to the law enforcement sub-program ${ }^{33}$ include:

- human resource development, awareness enhancement and motivation schemes;

- the need for urgent reform in management and staffing at training centres (including the police and prison administration);

- adequate budget to enhance the number and skills of researchers in the justice sector;

- $\quad$ support to and follow up of the law revision activities that are underway;

- schemes of support to encourage Alternative Dispute Resolution;

- the need for alternative punishment to avoid overcrowding of prisons which weakens the efforts of reform and rehabilitation in prisons; and

- strategies and directives that can facilitate the effective implementation of Ethiopia's Crime Prevention Policy.

The JLRTI study condemns human rights violations against detained

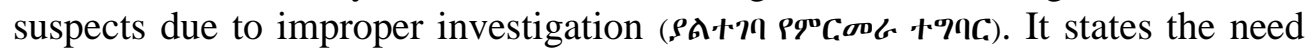
for the enhancement of technology, proper training in investigation, forensic labs and services, forensic pathology and forensic psychiatry, and enhanced public awareness about crimes. It also underlines the need for "prohibitive and deterrent measures against persons who conduct improper investigation against suspects who are under custody" 34 and demands the "provision of clean lodging, adequate healthcare and adequate food to suspects under custody as much as possible". 35 To this end, the study calls for harmonized pursuits among all justice sector institutions. ${ }^{36}$

\footnotetext{
33 Id. pp. 150-156.

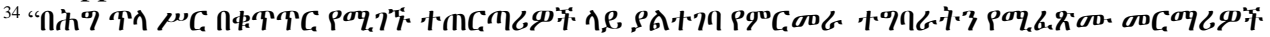

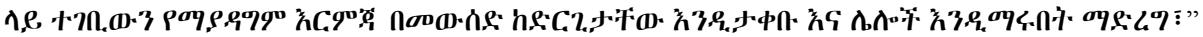

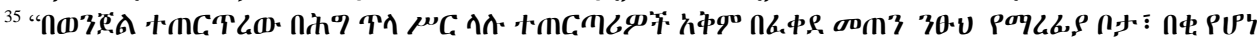

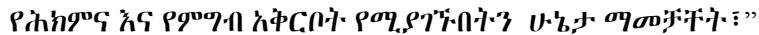

${ }^{36}$ Id., p. 153.

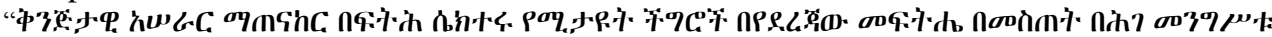

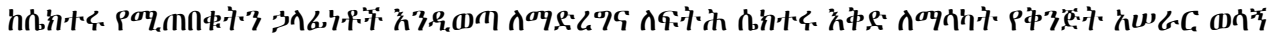

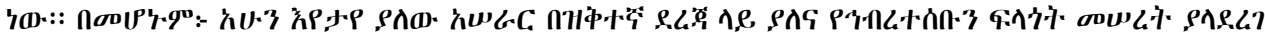

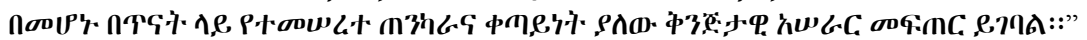


With regard to the legal education reform sub-program, ${ }^{37}$ the study, inter alia, calls for "staff development in post graduate and $\mathrm{PhD}$ programmes, pedagogy training, formulation of a system that implements admission exam to legal education in addition to the exit exam that is underway, and sustained review and updating of curriculum." Moreover, it underlines the need for "incentives to academics toward preparing and publishing law textbooks and incentive schemes to legal research and its implementation".

Various cross-cutting recommendations in the JLRTI study are stated under the law enforcement sub-program. The need to give due focus to the availability of required facilities are stated among the recommendations of the study. ${ }^{38}$ Moreover, the study notes the gaps in the justice sector with regard to harmonization, and calls for coordinated and harmonized activities because the level of operations in the justice sector is currently low and not in tandem with the needs of the public, thereby necessitating enhanced and harmonized modes of operations. ${ }^{39}$

The recommendations in the study further state the need for mechanisms that ensure legal aid through the enhanced participation of practicing lawyers and law schools, and for the representation of the indigent who should receive pro bono services in their claims of compensation as victims of serious crimes and human rights violations. With regard to professional associations, the study indicates the need for strengthening associations in the legal profession, and it states their prospective role in the efforts toward solving the problems in the justice sector. To this end, the study, inter alia, calls for due attention to a legal framework and a coherent institutional arrangement. ${ }^{40}$

Cross-cutting recommendations (in the section on law enforcement subprogram) include the enhancement of ICT and due attention to the effective and efficient legal information flow though the completion of the National Integrated Justice Information System /NIJIS (

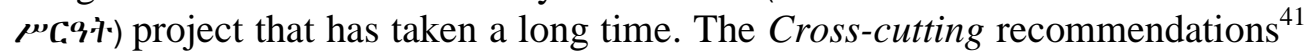
(that are stated under the legal education sub-program) include the need to establish institutional structures in all justice sector institutions that manage the justice system reform program and substantially enhance the capacity of JLRTI in expertise, resources and facilities commensurate with its functions. These recommendations further state the need to identify the projects under the justice system reform program that have not been implemented, and mobilize fund and manpower for their implementation.

\footnotetext{
${ }^{37}$ Id. pp. 157, 158.

${ }^{38}$ Id., p. 154.

${ }^{39}$ Id., p. 155.

${ }^{40}$ Ibid.

${ }^{41}$ Id., pp. 157, 158.
} 


\section{JLRTI's Mandates to Coordinate Justice Sector Reform -vis- à-vis- Gaps in Institutional Continuity}

As indicated in the preceding paragraph, there is the need for "substantial enhancement in the capacity of JLRTI in expertise, resources and facilities commensurate with its functions of supporting justice sector institutions". Even though the Federal Attorney General and JLRTI have overlapping functions in legislative drafting and law revision, the remaining components of justice system reform clearly fall under the responsibilities of the entities that are in charge of the respective sub-programs, thereby requiring follow-up, harmonization and coordination.

The Federal Supreme Court, the Federal Attorney General (which can coordinate the reform sub-programs of prosecution services and prisons), Justice and Legal System Research and Training Institute, and the Consortium of Ethiopian Law Schools are the entities in charge of the sub-programs in the justice system reform. At the level of coordination and harmonization, there should also be the representation of the legal profession through the Ethiopian Lawyers Association, which according to the 2005 Baseline Study Report, ${ }^{42}$ is expected to be recognized by law and be entrusted with tasks that include licensing attorneys and handling cases of discipline with due participation of other stakeholders including the Federal Attorney General.

Legal information is a cross-cutting component in Ethiopia's justice system reform program, and Article 4(2) of Proclamation No. 1071/2018 requires the Justice and Legal Research and Training Institute to make "available comprehensive information about the justice systems of the country" and "be a center of justice and legal information". In spite of this mandate, however, JLRTI does not even have an official website that has basic legal information. This clearly indicates budgetary, human resource and ICT constraints.

In 2016, JLSRI (currently restructured as JLRTI) was not willing to receive and administer fund from the African Law Library Project (under the African Innovation Foundation fund) towards the preparation and publication of EtLex Volume 2. As a result, the series titled EtLex could not be sustained. The volume was a sequel in the series of publications to enhance Ethiopian legal information by indexing proclamations and translating Federal Supreme Court Cassation decisions. The first volume of the project EtLex Volume $1^{43}$ was successful (in 2013), and the level of attention to the second phase of the project

\footnotetext{
${ }^{42}$ Baseline Study, supra note 2, p. 23 (The Judiciary, Recommendation No. 15).

${ }^{43}$ EtLex, Volume 1, (2013), Ethiopian Legal Information Consortium, Selected Federal Cassation Decisions and Ethiopian Law Index (1995-2012), Published by Justice and Legal Systems Research Institute, December 2013.
} 
substantially declined in 2016. This shows that the challenges in continuity further involve gaps in the sustained pursuance of projects and tasks.

According to Article 5(4) of Proclamation No. 1071/2018, JLRTI has the responsibility of "coordinating, integrating and ensuring the effectiveness of the justice system and legal education reform programmes as well as other reform program carried out in the justice sector." Even though the Advisory Council (that is envisaged to be established under JLRTI Proclamation No. 1071/2018) is not expressly mandated to coordinate the reform tasks of justice sector institutions, Article 12(1) of the Proclamation clearly empowers the Advisory Council to serve as a forum where "federal justice organs shall work in collaboration in order to coordinate and facilitate the Institute's activities".

There is yet another restructuring based on Article $33(8)(\mathrm{d})$ of the Powers and Duties of the Executive Organs Proclamation No. 1097/2018 which has made JLRTI accountable to the Federal Attorney General's Office, by changing JLRTI's accountability to the Prime Minister's Office under Proc. No. 1071/2018. Under both proclamations, the Federal Justice Organs Professionals Training Center (JOPTC) which has merged with JLSRI (to form JLRTI) comes under the executive even though it, inter alia, offers judicial training. This inevitably necessitates undoing what was done, i.e., splitting JLRTI into JLSRI (Justice and Legal System Research Institute) and reinstituting JOPTC as a Judicial Training Center under the Federal Supreme Court.

There have been series of interruptions in institutional memory that have caused discontinuity in JLSRI's and JOPTC's tasks and services. Equally important is JLRTI (formerly JLSRI)'s location so that it can be convenient to attract and retain professional staff and be easily accessible to all stakeholders in justice system reform including the legal profession at large.

Unfortunately, however, this crucial factor of location has not been given due attention since JLRTI (formerly JLSRI) was forced to leave the compound of the Ministry of Finance and Economic Development (in 2010/11) while in fact at the current information age- the Ministry could have regarded the premises in its compound adequate for its functions. The new premises constructed past Ayat (at the outskirts of Addis Ababa), to be used by JLRTI, can only serve as a training center and not as premises to a legal research institute whose offices, facilities and library should be accessible (at a convenient location) to the justice sector, law schools, researchers and the legal profession at large.

\section{Caveats against Disrupting Institutional Continuity by Scrapping Entire Codes of Law in the Name of 'Revision'}

While law reforms in areas such as Ethiopia's anti-terror legislation, the proclamation on civil societies, etc., are expedient, there is the need for caution against trends in law revision that aim at scrapping the codes of law enacted in 
the 1960s. This author has expressed the views indicated in the following paragraphs to colleagues at the Justice and Legal Research and Training Institute $^{44}$ and the Federal Attorney General ${ }^{45}$ regarding the need for caution in the course of revising the Civil Code and the Commercial Code.

The view which considers the Civil Code as outdated (merely because it was enacted fifty-eight years ago) is not persuasive even though there are indeed Civil Code provisions that need reform. Yet, the 'age' of the Codes is repeatedly stated at the opening statements of various (Codes of Law Revision) workshops. Of course, there are parts of the Civil Code that have already been replaced, such as land law, intellectual property law and family law. But in various parts of the Code, including the issue of family name in law of persons, we have not yet attained some of the objectives that were envisaged. Unfortunately, we tend to radically negate the past (analogous to throwing away a child with the bathwater), and build up afresh (which is unwise). For example, the codes of law in France are over two hundred years old, and new changes stand over the shoulders of the preceding laws.

In our case, we rush to change rather than merely amend the ones that are obsolete. As a French proverb goes, "plus ça change, plus c'est la même chose" ("the more things change [fast], the more would they remain the same"). In some of the revisions, unnecessary confusion is created, because the Criminal Code, for example, could have been revised without substantial change in the number designations of the provisions. With careful drafting, most provisions could have retained their numbers as it is duly done in Articles 1-33, 46-47, 4853, and 56-59 of the 2004 Criminal Code.

The inclusion of Article 34 on corporate criminal liability, for example, was indeed appropriate. The title of Article 32 could have been amended as "Principal Criminal Liability and Special Crimes" to accommodate Article 33 of the 1957 Penal Code as Article 32(4) of the 2004 Criminal Code. This could have enabled corporate criminal liability to be designated as Article 33 without disturbing Articles 34 to 45 . This could have been done throughout the Code thereby retaining the judicial jurisprudence and academic literature that was accumulated from 1957 to 2004.

The same applies for provisions that may be omitted during revisions of other codes of law because a preceding or an immediately following provision can be split into two in order to maintain sequence in subsequent provisions. In the case of substantial omissions, amendments can state the numbers omitted and then proceed with the old sequence. Where there is a substantial insertion of

\footnotetext{
4427 April 2018.

45 June 2018.
} 
new provisions, alphabetical designations can be attached to numbers, as is the case of amendments to the 1804 French Civil Code that has periodically updated consolidated versions. Likewise, the Swiss Civil Code of 1907 updates the Code with new changes rather than scrapping it en toto.

This facilitates the transmission of judicial decisions and academic literature to generations, because in continental legal systems, court decisions and academic literature cite provisions and not cases thereby rendering easier reference to the number designations of provisions very important. In this regard, we can draw lessons from the drafter of the 1957 Penal Code, Professor Jean Graven, his team and the legislature for having used 120A after Article 120. The drafter did not originally include flogging as punishment, but the issue of lashes to a maximum of 'arba jiraf' (forty lashes) was persistently raised as traditionally important by certain members in the legislative process, and the drafter had no option, other than including it.

However, the drafter was aware that flogging will be obsolete after certain years owing to Ethiopia's steady interactions with the international community and in the course of legal development in Ethiopia. It was not thus given a number on its own (i.e. Article 121), but was included as Article 120A. As proactively envisaged by the drafter, the provision was obsolete (after a few years) in courts of law. The Civil Code can thus be amended without scrapping it aside.

The same holds true for the Commercial Code because most of the numerical designations of the earlier Commercial Code can be maintained with careful draftsmanship. This can be done by blending immediately preceding (or subsequent) provisions to accommodate newly inserted provisions. Changing the entire numerical designations of the Commercial Code including various landmark provisions would mean throwing away our legacy that is accumulated since the 1960s in textbooks, scholarly articles, judicial decisions, etc., which cite specific provisions. One of the problems in Ethiopia relate to our inability to stand over the shoulders of earlier achievements (while we could have focused on what needs to be corrected and developed). To borrow a phrase from Dr. Mehret Debebe's statement (during a radio interview), it is always wise to consider the "ceiling of an earlier achievement" as the "floor for new pursuits."

Where consistency in numerical designation becomes impossible (while revising some parts of codes of law), the usual practice is to let the specific branches of the law emerge and stand on their own feet. With regard to the Commercial Code, there is apparently the need for responding to the steadily unfolding realities which require changes in the formation and operation of companies. However, this can, for example, be accommodated by a new law that can be designated as Ethiopian Law on Commercial Companies, analogous to the laws on insurance, banking etc, that have already stood on their own feet even if certain provisions of the Commercial Code are still relevant to the 
sectors. Under this option, the (1960-2018) judicial jurisprudence and literature related to the 1960 Commercial Code can stay undisturbed (because there would not be namesake/q'n'í, confusion).

\section{The Nexus between Good Governance and Justice Sector Reform}

Worldwide good governance indicators ${ }^{46}$ include six dimensions of governance:

"1. Voice and Accountability (VA): ...the extent to which a country's citizens are able to participate in selecting their government, as well as freedom of expression, freedom of association, and a free media.

2. Political Stability and Absence of Violence/Terrorism (PV): ... the likelihood that the government will be destabilized or overthrown by unconstitutional or violent means, including politically motivated violence and terrorism.

3. Government Effectiveness (GE): ... the quality of public services, the quality of the civil service and the degree of its independence from political pressures, the quality of policy formulation and implementation, and the credibility of the government's commitment to such policies.

4. Regulatory Quality (RQ): ... the ability of the government to formulate and implement sound policies and regulations that permit and promote private sector development.

5. Rule of Law (RL): ...the extent to which agents have confidence in and abide by the rules of society, and in particular the quality of contract enforcement, property rights, the police, and the courts, as well as the likelihood of crime and violence.

6. Control of Corruption (CC): ... the extent to which public power is exercised for private gain, including both petty and grand forms of corruption, as well as "capture" of the state by elites and private interests". 47

These six dimensions are enablers for Ethiopia's justice system reform. The first dimension (Voice and Accountability) is a sine qua non condition for a competent legislative body and independent judiciary. The legitimacy of governments under theocracy, monarchy, communism, etc. is attributed to

\footnotetext{
${ }^{46}$ The World Bank, Worldwide Governance Indicators <http://info.worldbank.org/governance/wgi/index.aspx\#home>

${ }^{47}$ Daniel Kaufmann, Aart Kraay and Massimo Mastruzzi (2010), The Worldwide Governance Indicators: Methodology and Analytical Issues, Global Economy and Development at Brookings, p. 4.

For further discussion on in the application of the six dimensions to justice sector reform, see Stebek (2016), Ethiopia's Justice Sector Components in GTP I and II, Ethiopian Lawyers Association (pp. 74, 75).
} 
factors other than the ballot box. On the contrary, governments that claim to pursue constitutional democracy attribute their legitimacy to elections. Whenever governments use the ballot-box as a façade, they intervene in the operations of public prosecution services, the judiciary, electoral boards/ commissions, the media etc., to suppress opposition political parties; and they operate in the context of a rubber-stamp parliaments and non-independent judiciary.

The second dimension (Political Stability and Absence of Violencel Terrorism) can be related with the population's perception of government legitimacy. It can also be related with various social and economic grievances. Societies that are polarized due to religious, ethnic and clan hostilities are mostly volatile. Elites usually hijack and exacerbate such hostilities towards economic and political 'gains', although they usually end up in 'lose-lose' scenarios.

Laws envisage compliance, and violations are regarded as exceptions. However, order and stability are disrupted where mobs (in the crude form of ochlocracy) take the law into their hands. This not only reflects lawlessness, but it is also a symptom of erosion in the fabric that holds neighborhoods, communities and a society together. Achievements in Ethiopia's justice system reform thus, inter alia, depend on the extent to which the root causes for such acts are addressed.

The core foundation of terrorism is one of the basic emotions in human beings, i.e., 'anger-fear'. In their positive dimension, 'anger' secures justice (as in the case of an infant whose toy is unduly taken by another child, civil disobedience, legitimate strikes, etc,); and 'fear' facilitates survival (as in the case of subconsciously-enhanced pace in running from an aggressive wild animal). These basic emotions of 'anger' and 'fear' can be distorted in the course of ideological, ethnic or religious fanaticism, or as over-reaction in the course of counter-terrorism. ${ }^{48}$

The third dimension of good governance (Government Effectiveness), inter alia, relates to the quality of public services (including justice sector institutions) and the degree of "independence from political pressures". The scene of widespread street vending at various parts of Addis Ababa clearly verifies the gaps in the effectiveness of law enforcement and its inability to protect tax payers from the wave of contraband merchandise. One can, for example, recall the effectiveness of community guards in Merkato (for many years) while they were under a business development association. A letter from

\footnotetext{
${ }^{48}$ Author's reflections in email exchange with a staff member at Education for Justice (E4J), United Nations Office on Drugs and Crime, 6 August 2018.
} 
the Chief Executive Officer of the Sub-city, ${ }^{49}$ repealed the earlier practice, and the community guards operate under a Police Station since November 2016. Merkato is engulfed in street vending during the last two years. While the former option was effective governance with the participation of stakeholders, the latter represents regulation under a government organ without stakeholder engagement.

Gaps in government effectiveness are reflected in various public services. For example, streets (through tacit or explicit ultra vires consent of municipal offices) are illegally enclosed by individuals as in the case of a building construction work that has (for about three years) blocked a street between the building where Flamingo Café (Bole Road) is located and Tomy Tower.

The fourth dimension of good governance (Regulatory Quality) is, inter alia, manifested by the extent to which policies and laws "permit and promote private sector development" thereby enhancing livelihoods which include economic efficiency and social well being in the context of environmental sustainability. There are concerns such as the need for land tenure security which require revisiting Ethiopia's rural and urban land laws because Ethiopia's land laws do not empower broad-based private sector development. As indicated in various studies (such as the ones highlighted in Section 9 below), there is the need for legal regime reforms toward private sector empowerment in the context of inclusive economic development whereby landholders and entrepreneurs can team up in win-win economic activities. Absence of stock market in Ethiopia is another issue that needs regulatory attention to enhance broad-based saving and investment.

Regulatory quality further envisages harmonization and professionalism in legal drafting and promulgation. For example, various institutions haphazardly incorporate 'penal' provisions thereby creating fragmentation and confusion in the criminal law regime. This is inconsistent with Article 3 of the 2004 Criminal Code which allows other penal legislation (outside the Criminal Code) as an exception only when it is enacted as a regulation to enforce the Criminal Code, or if it is enacted as a special law of a criminal nature.

There is extensive discourse and literature on the challenges in the fifth and sixth dimensions of good governance, i.e., gaps in 'rule of law' and 'control of corruption' in the context of Ethiopia. The apparent gaps in the fifth dimension include problems in contract enforcement and property rights protection. Moreover, the impediment in the sixth dimension, i.e., level of corruption deserves utmost attention. These challenges call for due attention to the root

\footnotetext{
${ }^{49}$ Letter from the Sub-city to Woreda 5 General Business Persons Business and Development, Tikimt 21, 2009 Ethiopian Calendar (October 31, 2016).
} 
causes, while at the same time steadily combating their manifestations and effects.

\section{The Tension between Ethnic Hostilities and Good Governance}

The first dimension of good governance, i.e., voice and accountability embodies two elements. As highlighted in the preceding section, the first element (voice) refers to 'the participation of citizens in selecting the government', while the second element refers to the extent to which the government is accountable, which includes freedom of speech, freedom of association and the media. Both elements are indispensable in good governance.

Good governance is an enabler in all pillars of justice sector reform. Ethnic hostilities impede the attainment of both limbs in the first dimension of good governance. Under settings where ethnic hostilities and extremist perceptions of ethnic distinctiveness are entrenched, a minority ethnic group that coercively holds power inclines toward vote rigging, manipulating elections and intervention in electoral boards/commissions because most voters tend to cast their votes to candidates who belong to their ethnic group. A minority ethnic group that is coercively in power cannot thus retain office through free and fair elections under ethnic polarities thereby rendering transgressions against rule of law and judicial independence its modus operandi.

Such ruling parties invest much energy, time and finance to manipulate constituencies before elections, and devote equal attention to post-election justifications and show trials after the elections (which in the Ethiopian context included 'anti-terrorism' charges and convictions). Under this setting, governments are mostly trapped in a 'legitimacy' syndrome, and only a small percentage of their 'term' (between 'elections') is devoted to governmental functions. Such 'legitimacy' syndrome is also susceptible to fraudulent reporting of 'achievements' (in development pursuits) as a result of fixations on unduly exaggerated figures and statistics rather than pragmatic and functional achievements commensurate with the requisite pace, quality and standards.

On the contrary, a political party (in ethnically polarized societies) from an ethnic group (that constitutes the majority of a country's population) does not need to manipulate elections unless there are competing ethno-radical candidates in similar constituencies (with substantial support-base) from the same ethnic group. Even though such ethnic-based political parties may not usually resort to fake elections, they may not enthusiastically pursue the second limb in the first dimension of good governance, i.e., accountability. This is because their political offices are mainly secured by ethnicity rather than policy roadmap, competence, integrity and commitment. Such candidates may lack sense of accountability to citizens in their constituencies. 
Ethnic groups in Ethiopia constitute the majority in most of the regional states in Ethiopia other than Southern Nations, Nationalities and Peoples Regional State (SNNPRS) and the two chartered cities, i.e. Addis Ababa and Dire Dawa. Ethnic politics can thus erode accountability and enhance ethnocentric populism in the regional states. Such contest in populism between ethnic-based political groups in their constituencies is susceptible to an adverse race in ethnic radicalism to win the impressions and sentiments of the electorate in lieu of rational ideas. Such extreme political polarities accompanied by the proliferation of political parties can significantly hamper post-election policymaking and legislative productivity.

Opportunities in this regard relate to the coalitions and political platforms which can eventually lead to their merger onto multiethnic political parties. For example, EPRDF (Ethiopian Peoples Revolutionary Democratic Front) is, at some point, expected to omit the qualifier 'revolutionary' when it fully disentangles itself from its Leninist ideological heritages (of the "New Democratic Revolution') even if it can still remain within the social democratic fold. At such a stage, the word 'Front' is expected to be revisited and substituted by a word which fits to its current and upcoming policy roadmaps.

Ethiopia's experience indicates that the second dimension of good governance (i.e. political stability and absence of violence) cannot be attained in the context of ethnic hostilities. Plutchik's views on pairs of emotions (such as joy-sadness, anger-fear, trust-disgust, surprise-anticipation $)^{50}$ provide insights into the basic emotions of individuals that can be manipulated by radical ethnonationalists. A provocation by a certain group evokes anger and chain of negative emotions which trigger further reactions based on revenge, distrust and fear thereby rendering peace, governance through law and rule of law difficult.

Fraternity based on shared citizenship and trust is susceptible to erosion under ethnic hostilities, and on the contrary, distrust entrenches fear and anger thereby making it difficult for the justice system to ensure order and political stability. The current digital age and social media exacerbate these challenges owing to the ease, magnitude and pace of dissemination including manipulative misinformation. Actual and anticipated ethnic-based or religion-based hostilities adversely affect political stability, social harmony and economic performance thereby rendering it difficult for the justice system to ensure law and order.

Politics per se is based on rational discourse and shared citizenship, while ethnic 'politics' primarily targets at emotion and claims of common descent,

50 See for example, Robert Plutchik (1980), A general psychoevolutionary theory of emotion. In R. Plutchik \& H. Kellerman (Eds.), Emotion: Theory, research, and experience: Vol. 1. Theories of emotion (pp. 3-33). New York: Academic. 
language and distinctiveness. Ethnic-based politics thus renders it difficult to attain the first two dimensions of good governance. This cascades to the other dimensions, because gaps and challenges in the first and second dimensions of good governance have direct relationship with the remaining four dimensions, i.e. government effectiveness, regulatory quality, rule of law and effective control against corruption that are adversely affected by ethnic-based politics.

\section{Law Compliant Citizenship and Justice Sector Effectiveness}

\subsection{The need to restore public trust}

Public service constitutes the raison d'être of justice sector institutions, and public trust in the justice system is determined by the level and quality of actual performance. Restoration of public trust, after its substantial decline, can be compared with land reclamation through the rehabilitation of degraded agricultural land due to grave problems such as gully erosion. As Lal noted, "[a]n eroded rill, on deepening and widening, becomes a gully. A gully is sufficiently deep that it would not be obliterated by normal tillage operations, whereas a rill is of lesser depth and would be smoothed by ordinary tillage". ${ }^{51}$

As gully erosion cannot be restored by ordinary tillage, the gravity of the problems in Ethiopia's justice system requires a thorough self-assessment of the sub-sectors. It also needs survey-based assessment on the gravity of the problems with due participation of stakeholders so that the magnitude of the problems can be identified based on Truth and Reason. This is because laws and the institutions in charge of lawmaking, adjudication, enforcement, legal education and access to justice that are not informed by Truth (in terms of objective and subjective realities) and Reason cannot be effective.

In the gully analogy, the act of restoring a gully cannot be adequate unless its root causes are addressed. Such measures include the need to deal with the problem such as concentrated runoff of floods that caused the gully. Likewise, there should be deeper examination into the root causes that have adversely affected the operations and services of justice sector institutions. Such deeper diagnosis and effective pursuits call for the blend between autonomy and harmonization in the reform pursuits of each sub-sector.

\subsection{The need to enhance law compliant citizenship}

In the absence of law compliant citizenship, the justice sector becomes susceptible to caseloads in investigation, prosecution and adjudication that impede efficiency and effectiveness. Various factors such as widespread public perception of illegitimacy of a government in office, dwarfed moral authority of

\footnotetext{
${ }^{51}$ Rattan Lal (1992), 'Restoring Land Degraded by Gully Erosion'; in Advances in Soil Science, Volume 17, Springer-Verlag New York Inc., p. 123.
} 
corrupt office holders, and wrong policies erode law compliant citizenship. This, in the Ethiopian context, is exacerbated by ethnic-based perceptions of "we" and the "others" that have been nurtured by the political leadership during the past decades.

We can, for example, recall Aristotle's view that good thoughts lead to good actions, and can through repetition become good habits and good character. On the contrary, thoughts that emanate from misrepresentation, ideological 'indoctrination' and hatred-infested politicking (including social media hate scripts) are distorted and usually antagonistic. It is thus Truth and Reason that can create shared beliefs and positive thoughts that are in tune with the reality, general will and the rule of law.

Manipulation of emotions through misrepresentation is a breeding ground for irrational hostilities and lawlessness, while reason nurtures inquiry, moral standards, work ethic, quality education and law compliant citizenship. Wider scope of freedom in a legal regime presumes higher levels of awareness and moral responsibility from citizens. On the contrary, substantial reform in a legal regime can unmask the level of hostilities, intolerance and gaps in political culture that were concealed under suppressive regimes. Under settings where legal regimes with wider levels of freedom are accompanied by the requisite level of law compliant citizenship, professional associations nurture and control occupational conduct, and the society's value systems are among the core sources of individual moral standards.

The ethnic hostilities that are occurring in Ethiopia illustrate gaps in law compliant citizenship. It is in spite of Ethiopia's criminal law regime that the Jigjiga tragedy, for example, occurred on August 4, 2018. It was unimaginable that the heavy loss in life and property including arson against churches would occur in a country which is known for the level of tolerance and cooperation among religions. As Basu observes:

The might of the law, even though it may be backed up by handcuffs, jails, and guns, is, in its elemental form, nothing but a structure of beliefs carried in the heads of all the people in society-from the ordinary citizenry to the police, politicians and judges_- intertwining and reinforcing one another, till they become as strong as concrete structures ... . The most important ingredients of a republic, including its power and might, reside in nothing more than the beliefs and expectations of ordinary people going about their quotidian chores. $^{52}$

\footnotetext{
${ }^{52}$ Kaushik Basu (2015), “The Republic of Beliefs: A New Approach to 'Law and Economics'," Policy Research Working Paper 7259 (Wold Bank Group Development Economics Vice Presidency, Office of the Chief Economist, May 2015), p. 15.
} 
Any meaningful reform in lawmaking and revision should thus pay attention to the beliefs and expectations that have brought about the actions of citizens such as the Jigjiga hostilities, Gedeo and West Guji zone conflicts and ethnic displacements. In September 2018, these hostilities and displacements continued, in various parts of Ethiopia such as Burayu, Benishangul Gumuz Regional State (Kamashi Zone), and others. Even though Ethiopia is not yet a fragile state (a phase that signals the prelude to failed statehood), ethnic hostilities and the perceptions that trigger them need to be carefully examined in the course of justice system reform. The magnitude of the problems in this regard can be easily verified by the fact that Ethiopia has become a country with the largest displaced population in the world due to ethnic clashes. ${ }^{53}$

It is becoming common to equate the word 'hizb' with ethnic homogeneity (in a regional state) as a semantic referent. This approach entrenches the dichotomy of "we" and "the rest other than us" in the minds of linguistic groups. Such perception erodes sense of citizenship and can be easily hijacked by ethnic entrepreneurs who speculate toward economic gains and political power. If we opt to use the word 'hizb' at sub-national level, it should have

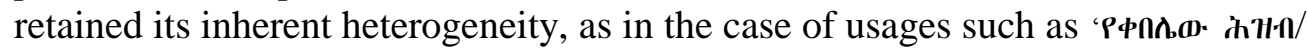
people in the Kebele' which refers to every resident irrespective of ethnicity and religion. Any different usage is expected to have a qualifier to show specific reference.

Professor Bahru Zewde had (at a workshop) suggested that we use the phrase

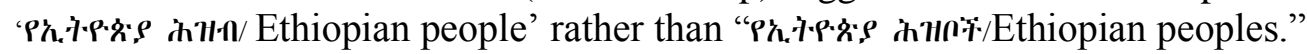
It is thus high time that views of historians, sociologists and other experts on their respective fields be seriously considered in the context of critical thinking and informed discourse. The following observation by Kymlicka shows the need for caution in the use of the word "peoples' rather than 'people" in the context of a country's population:

... Multinational federalism divides the people into separate 'peoples', each with its own historic rights, territories, and powers of self-government; and each, therefore with its own political community. They may view their own political community as primary, and the value and authority of the larger federation as derivative. ${ }^{54}$

Kymlicka further states that in order to reduce this danger of deep division, "federal governments have encouraged national minorities to identify with, and feel loyalty towards, the federal government", and he notes that "the historical

\footnotetext{
${ }^{53}$ See for example, Addis Standard, September 12, 2018.

${ }^{54}$ Will Kymlicka, Federalism, 'Nationalism, and Multiculturalism' in D. Karmis et al. (eds.), Theories of Federalism: A Reader [in Dimitrios Karmis and Wayne Norman 2005;

Chapter 24], p. 287. (Citing OECD)
} 
record suggests that these efforts have limited success". 55 Attainments in this regard thus need due attention to the root factors transcend official statements and pledges.

There have been challenges in maintaining the proper balance between ethnic identity and sense of membership in the bigger Ethiopian political community. In this regard, there were earlier symptoms of ethnic tensions that could have served as wake-up calls. Physical assaults in university campuses and soccer games that reflect ethnic tension could have been regarded as symptoms in diagnosing the problems. On the contrary, there are Ethiopian universities that are becoming hubs for ethnic-based student groupings and tensions, while they should have been forums for rational discourse, critical thinking and cosmopolitanism.

Ethnic hostilities indeed affect nation-building. As René Grotenhuis notes, the "process of nation-building boils down to 'forging a sense of common nationhood', 56 and he raises the following issues:

How can we make sure that Luos and Kikuyus identify themselves as Kenyans and that the Kenyan nationhood is an important aspect of their identity? The same challenge goes for people of different ethnic and tribal affiliations ... .

... [I]n many fragile contexts, the state is absent or, worse, a perpetrator of acts of violence. In such a reality, people look towards their family, tribe, clan or religious community to find protection and to access basic needs like food, shelter and medical care. ${ }^{57}$

Grotenhuis uses a model formulated by Shulman in his discussion on the components of national identity. According Shulman, there are three layers of collective identity, i.e., ethnic, cultural and civic. The first layer (i.e. ethnic identity) is based on ancestry and race, while the second layer (cultural identity) is based on [factors such as] language and tradition. Civic identity that is shared by all citizens is the third layer which is based on citizenship, territory, will and consent, political ideology, political institutions and laws.

Shulman's three main elements (civic identity, cultural identity, ethnicity) and their underlying components are the building blocks of a national identity, but their relative importance of weight is not defined in advance. It is an open model that leaves space for a contextual and diverse understanding of national identity. ... What is at stake is not the objective truth about the

\footnotetext{
${ }^{55}$ Id., p. 292, Endnote 26.

${ }^{56}$ René Grotenhuis (2016), 'National identity: A model and its content', in Nation-Building as Necessary Effort in Fragile States, Amsterdam University Press), p. 125.

${ }^{57}$ Ibid.
} 
different elements and components and their relative importance, but the extent to which people actually use these labels to define their national identity. ... If we want to build a national identity, this will have to be a bottom-up process. ${ }^{58}$

Various Ethiopian laws including the FDRE Constitution use nations, nationalities and peoples without clarity in definition and context. There should have been caution in using the word 'nation' for pre-industrial ethno-cultural groups of people, unless it is used in a country-wide context of nation-state or nation-building. Such conceptual clarity could have facilitated harmony among the triadic elements of a person's collective identity (i.e., ethnic, cultural and national identity, with the latter representing Ethiopian identity).

The following conversation between Dr. Alex de Waal ${ }^{59}$ and the late prime minister, Meles Zenawi (while the latter was alive) relates to nation building:

Question (Alex de Waal):

...[A]ny attempt to define nations and nationalities in a non-industrial society involves applying a set of more-or-less arbitrary criteria concerning language, culture, territory, etc. If the criteria are adjusted even ever-soslightly, the groups or populations that are identified as nations will alter, their boundaries will change, etc. [Secondly] ... economic development ...will change the character of those national entities. People will migrate, they will be organized differently, cultures will change. This is normal. So how will your definition of 'nation' change as Ethiopia industrializes? And what does this mean for the constitution? ${ }^{60}$

Response (Meles Zenawi):

This is a critically important point that we have not resolved. It may be the most politically sensitive and explosive question that we need to face. Our federal formula was devised during the transition in negotiation with the OLF. ... They regressed to a narrow nationalism that is the obverse of developmentalism or democratic nationalism. Meanwhile, the chauvinists adopted another pathology of nationalism, inherited from the feudal-imperial past, of a pan-Ethiopian chauvinism that refuses to recognize other nationalcultural entities as equals. For us to move forward, it is absolutely essential that the equal status of nations and nationalities is not only enshrined in the

\footnotetext{
${ }^{58}$ Id., pp. 128, 129.

${ }^{59}$ Alex de Waal (2018), The Future of Ethiopia: Developmental State or Political Market Place? August 20, 2018 (Executive Director at the World Peace Foundation at The Fletcher School, Tufts University, and Research Program Director): http://www.africanidea.org/The-future-of-ethiopia_development.pdf

${ }^{60}$ Id., pp. 6, 7.
} 
Federal Constitution but is internalized as part of our common political discourse. This is the foundation of democratic nationalism. ${ }^{61}$

The late prime minister's response is clearly untenable because political polarities are not managed through explosive experiments that are more harmful than the problems they are meant to resolve. This risky experiment can clearly be observed from the minutes of the Transitional Government of Ethiopia (TGE) during the seven meetings of the Council of TGE (mostly constituted of ethnic-based political groups that were members of the TGE) held on Meskerem 6, 8, 20, 22, 24, 27 and 29 in 1984 Ethiopian calendar (i.e. September/October 1991). With regard to the determination of regions/ kilils, the minutes of the Council of the TGE state the following views that were expressed by Councils's chairperson, the late Prime Minister Meles Zenawi:

The chairperson stated that the criteria for the delineation of regions/kilils is a basic issue; language, geographic adjacency and psychological make-up are adopted by the Council as criteria. The issue of nation or nationality is not biological but a historical process. This recognizes irreversible historical phenomena that are positive and negative. Or else, conflicts will ensue. For example, it can be said that most of the northern part including Tigray, Godjam, Gondar and Wollo were originally Agaw, and orgin cannot be the premise [criteria for regions]. The actual realities indicate that many parts of Wollo that were Oromo communities are now Amharic speakers and there are communities that still speak Oromiffa. On the other hand, these communities are not adjacent to their [ethnic group], and it seems preferable to allow them to form their own Woreda Councils (Shengos). ${ }^{62}$

The Transitional Government of Ethiopia (TGE) was thus fully aware that the fourteen regions that were formed during the transition period (later reclassified into nine regions and two cities under the 1995 FDRE Constitution ${ }^{63}$ ) were based on linguistic lines and other factors such as geographic adjacency and psychological make-up, and not biological origin. In reality, however, the

\footnotetext{
${ }^{61}$ Id., p. 7.

${ }^{62}$ Minutes of Meskerem 22, 24 and 27, 1984 Ethiopian Calendar. Pages 11 and 12:

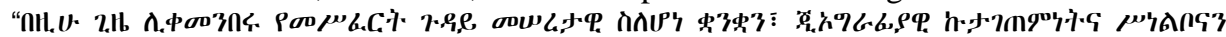

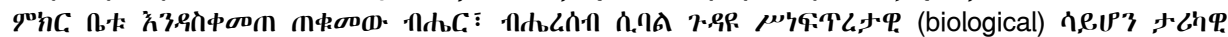

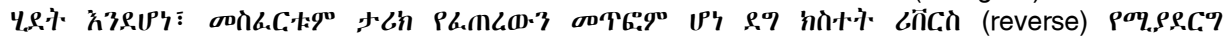

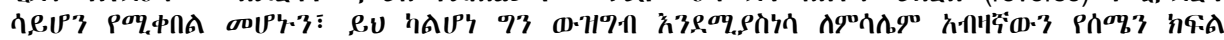

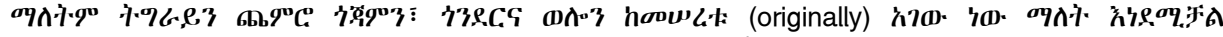

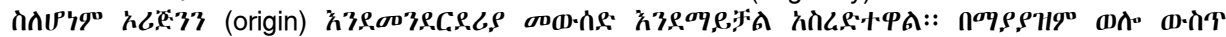

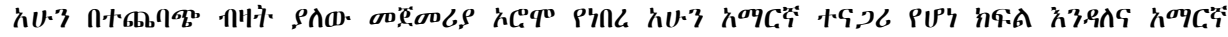

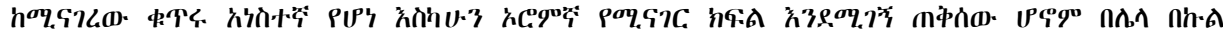

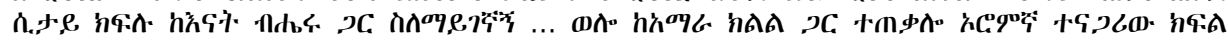
noL. 9 .

${ }^{63}$ Article 47, Sub-Article 1 of the 1995 FDRE Constitution
} 
experiment was susceptible to the creation of false consciousness towards biological/ethnic distinctiveness.

Alex de Waal was curious as to why EPRDF opted to adopt ethnic federalism that might not be conducive to changing realities in the course of Ethiopia's economic development. The following question relates to this concern:

But I still see some big problems. Nations are not static and unchanging, especially when they are entities within a 'nation of nations'. Isn't there a danger of getting stuck with a system that cannot adapt to historical changes - especially with the pace of economic development that is now occurring? ${ }^{6}$

The following was the response of the late prime minister:

That is why we are decentralizing important elements of governance, such as budgeting, to the zonal level and even lower. We need to have the right balance between the powers that are held at all different levels of government. If we invest too much in one single layer, there is the danger that the corresponding level of officialdom will become rent-seekers based on the outsized administrative privileges of that particular level. When the system was designed in 1991, the nations determined the administration. We want to avoid a situation in future where the administration determines the nations, which is what doomed Yugoslavia and the USSR.

There is also no reason why the EPRDF should be comprised of constituent parties that match the federal entities and are confined to them. There is no other federal system where party politics is run on this basis. We are considering making the EPRDF into a single unified national party. This would be a logical step, but it needs to be taken at the correct time with all the necessary preparation. ${ }^{65}$

The response of the late prime minister clearly shows the risks in regionbased party politics. He had also noted the need for the transition of EPRDF into a single unified party. However, the challenge that may adversely affect the pace of reform towards EPRDF's transition to a multinational party can be the competition of EPRDF members with other ethno-radical parties for wider support base (in their constituencies) which can promote ethnic-based populism.

The current major "obstacles and challenges" in Ethiopia's nation building pursuits "come from populisms animated by rival nationalisms, and their possible entanglements with organized politics". ${ }^{66}$ Current realities clearly

\footnotetext{
${ }^{64}$ Minutes, supra note 62.

${ }^{65}$ Ibid.

${ }^{66}$ Andreas Eshete and Samuel Assefa (2018), "Reflections on Expanding Ethiopia's Democratic Space”, pp. 42-49 in Reflections on Expanding Ethiopia's Democratic Space
} 
indicate "a growing divide among the nationalist populisms and an effort by regional parties or their rivals to win the support of populist movements."

Political platforms relate to competing rational ideas and not ethnicity. For example, Ghana's Constitution prohibits the formation of political parties that are tribal or ethnic based. It provides that "Every political party shall have a national character, and membership shall not be based on ethnic, religious, regional or other sectional divisions". ${ }^{68}$

The way forward in the path of effective nation building thus envisages a legal regime that encourages multi-ethnic political party formations, and the inclusion of non-ethnic members in ethnic based political groups which can lead to broader multi-ethnic political platforms. Positive developments in this regard relate to the reform processes in member parties of EPRDF that have expressed their intention to allow membership to non-ethnic residents of their respective regions who support their political programmes. Meanwhile, mass organizations, civil societies and other entities are expected to conduct various activities to protect collective rights which can, indeed, include ethnic and religious groups.

\section{Peace, Order and Stability in the Context of Diversity}

As peace (order) and freedom are two sides of the same coin, rule of law is unimaginable in the context of disorder and lawlessness. The latter not only affects the lives and property of citizens, but also exacerbates mass encroachments to forests, fragile landscape and wildlife. Polarities -which can ultimately bring about fragility and failed statehood- need not necessarily be among different linguistic and religious groups. It is to be noted that shared language and religion did not save Libya or Yemen from such tragedies.

Upon the disruption of the social fabric of a society -including value systems of pluralism, tolerance and fraternity- the effectiveness of laws and justice system institutions decline. In effect, individuals, gangs and mobs merely pursue their whims that trigger attacks, counter-attacks and hostilities. It is under such settings that virtues in the inner-self of many citizens dwindle. Subsequent realities can then bring about a chaotic setting that was explained by Thomas Hobbes (1588-1679) based on his observations during prolonged civil wars in Britain. Such chaos and anarchy can only lead to tyranny under a 'supreme sovereign' in the quest for order rather than rule of law.

\footnotetext{
Aspirations, Opportunities, Choices, p. 45. Available at: http://fes-ethiopia.org/wpcontent/uploads/2018/12/Printing-Version.pdf

${ }^{67}$ Ibid.

${ }^{68}$ Article 55 (4), The Constitution of the Republic of Ghana, 1992.
} 
The way forward does not lie in the Ethiopian unitary state, which unlike countries such as France, has not become successful in Ethiopia during the pre1991 regimes. Nor can ethnic radicalism bring about the balance between unity and diversity. There is thus the need to address the causes of the disequilibrium in the unity and diversity nexus while at the same time dealing with the symptoms in the course of justice system reform (including legislative reform).

Mere enactment of laws that deal with individual freedom in a multinational state "overlooks the fact that people identify with their particular community on the basis of their special or distinctive features...". ${ }^{69}$ Respect for diversity thus becomes inevitable in multiethnic societies. However, the notion of diversity can be misconstrued by ethno-radicalism which "includes all political endeavour that bases the distinction between friend and foe on ethnic characteristics and pursues its aims accordingly, even by violent means". ${ }^{70}$ This causes ethnic conflict in multinational states as long as the foundations are ripe. As Feiner observes:

If one wishes to search for new state concepts that could prevent ethnic conflicts or at least manage them peacefully, one needs to know the real causes of such conflicts. However, the views and theories as to the causes are as diverse as the conflicts themselves. Possible causes include:

- economy (social injustice),

- history (retaliation for historical injustice, denial of self-determination, historical discrimination),

- ethnic communities living in foreign neighbouring territory, religious fundamentalism,

- power-hungry warlords,

- fear and mistrust as consequence of terrorism of minorities and terrorism of the state. ${ }^{71}$

These objective realities constitute foundations for ethnic conflict that can erupt when the subjective conditions are ripe. As Feiner notes, the factors indicated above are "in some way related to the issue of ethnic identity and the attendant self-awareness", and he states that "the ethnic dispute is marked by a friend-foe mentality, which can be manipulated and radicalised by various private interests. Ethnic differences can be emotionalised in order to pursue economic, political, cultural or mere power interests, or to divert attention from other internal problems". ${ }^{72}$

\footnotetext{
${ }^{69}$ Thomas Feiner (2009), 'The Multicultural State: The Challenge of the Future' in Thomas Feiner \& Lidija Basta Feiner (2009), Constitutional Democracy in a Multicultural State and Globalised World, Springer, 8, p. 513.

${ }^{70}$ Id., p. 516.

${ }^{71}$ Id., p. 519.

${ }^{72}$ Ibid.
} 
While democracies are based upon the majority principle, addressing ethnic tensions calls for legal regimes that at the same time ensure equal treatment "as an individual as well as a member of an ethnic community or collective" in the absence of which the majority rule can "degenerate into a tyranny over minorities".

If states want to hold different ethnicities together, the majority will have to grant minorities the right to be recognised as ethnic units or communities on equal footing with other ethnicities including the ethnic majority. It is not enough that people as individuals are treated equally. It is essential that members of minorities can see themselves as belonging to an ethnic unit or group, which as a collective entity is on an equal footing with all other communities within the state. ... ${ }^{73}$

In the course of ensuring equal treatment and freedom of citizens as individuals and as an ethnic or religious collective, the "multicultural state can set itself the goal of holding society together by regarding diversity not as a burden but as an asset, and by fostering diversity as something that enriches society rather than merely 'tolerating' diversity". 74

How can cultural diversity be fostered? The only known means to foster diversity is to not only grant rights and liberties to the various communities, but to also equip them with the necessary autonomy to develop themselves according to their own values. It is necessary to construct the constitutional framework in such a way that the vast majority of the population can identify with the multicultural state and can see it as 'their' own state ('we'). People within such a state should be able to find a common answer to the questions: What is good for us as a multicultural community and what is good for us as a collective community? ${ }^{75}$

Feiner substantiates his views by using the Swiss experience which shows that generally accepted political values can ultimately bind multinational units of the federation thereby making such societies to steadily enhance their integration through common values:

Given that the Swiss democratic polity has been organised around common interests and integration rather than (as in such homogeneous states as France and the United Kingdom) sectional conflict, the combat of interests, and clashing power, it has found a legitimate way to unite the existing diversity into a politically homogenous unit on the basis of generally accepted political

\footnotetext{
${ }^{73}$ Id. p. 525.

${ }^{74}$ Id. p. 527.

${ }^{75}$ Ibid.
} 
values. Compromise has thereby retained its legitimising function for the establishment of political and civic identity. ${ }^{76}$

This explains the reason why federations under communist dictatorships failed and led to dismemberment (the Soviet Union, Yugoslavia and Czechoslovakia), while on the contrary they succeeded in constitutional democracies. As Kymlicka notes,

On any reasonable criteria, democratic federations, as opposed to Communist federations, have been surprisingly successful in accommodating minority nationalisms. Both historic multination federations, like Switzerland and Canada, and more recent multination federations, like Belgium and Spain, have not only managed the conflicts arising from their competing national identities in a peaceful and democratic way, but have also secured a high degree of economic prosperity and individual freedom for their citizens. ${ }^{77}$

According to Kymlicka, this has been possible because "democratic multination federations have succeeded in taming the force of nationalism" and "[d]emocratic federalism has domesticated and pacified nationalism, while respecting individual rights and freedoms". ${ }^{78}$ He also states that many federal systems in democratic countries (such as the United States or Australia) "were not designed as a response to ethnocultural pluralism" as a result of which the federal units do not correspond in any way with distinct ethnocultural groups who desire to retain their self-government and cultural distinctiveness". He further notes that " $[\mathrm{t}]$ hese sorts of federal systems can be quite stable". ${ }^{79}$ It is also worth to note that such territorial federations (as in the case of the United States, Brazil, and others) can "worsen the position of national minorities", unless the decisions about boundaries and powers are "made with the conscious intention of empowering national minorities". ${ }^{80}$

On the other hand "nationality-based units will seek different and more extensive powers than regional-based units" assertion of self-government-namely, secession-has only been made by nationality-based units, whether it be in the former Czechoslovakia, Yugoslavia or the Soviet Union, not regional-based units". ${ }^{82}$ Kymlicka further examines the risks involved in nationality-based federations (as opposed to territorial federalism):

\footnotetext{
${ }^{76}$ Id., p. 633.

${ }^{77}$ Kymlicka, supra note 54, p. 269.

${ }^{78}$ Ibid.

${ }^{79}$ Ibid.

${ }^{80}$ Id., p. 276.

${ }^{81}$ Id. p. 277.

${ }^{82}$ Id. p. 278.
} 
... Where national minorities become politically mobilized in this way, secession becomes more feasible, even with the best-designed federal institutions. ...

... Multinational federations are often viewed by national minorities as if they were confederations. National minorities typically view themselves as distinct 'peoples,' whose existence predates that of the country they currently belong to. ...

... But the political perceptions of national minorities are unlikely to match these legal niceties. For them, the larger country feels more like a confederation than a federation, in the sense that the larger country's existence is seen as morally dependent on the revocable consent of the constituent national units. ... ${ }^{83}$

Contrary to these challenges, "the experience to date in the West suggests that democratic multination federations are remarkably resilient" mainly owing to the focus "on the intrinsic benefits of belonging to a federation-that is, the value of belonging to a country which contains national diversity". In the absence of balance between sense of belongingness to a federation and recognition of diversity, multination federal units in non-democratic countries regress culturally in addition to the risks of ultimate dismemberment. Upon the dissolution of Czechoslovakia, the following reflections from its former prime minister, Petr Pithart, show the magnitude of loss that Prague had encountered due to its failure to embrace diversity under communist regimes:

In the last 55 years, the Czechs have lost -as co-tenants in their common house- Germans, Jews, Ruthenians, Hungarians and Slovaks. They are now, in effect, an ethnically cleansed country, even if it was not by their own will. It is a great intellectual, cultural, and spiritual loss. This is particularly true if we consider central Europe, which is a kind of mosaic. We are still living touristically from the glory of Prague, which was a Czech-German-Jewish city and a light that reached to the stars. But you cannot win elections with that kind of argument. ${ }^{84}$

Kymlicka agrees with Pithart's reflections that there is often a 'great intellectual, cultural and spiritual loss' under such settings, but he believes that voters can indeed support candidates who oppose ethnically dichotomized constituencies depending on a country's history and the perception of most citizens. He underlines that "average citizens are capable of seeing the benefits of living in a multination federation, and of comparing it with the alternatives,

\footnotetext{
${ }^{83}$ Id. pp. 286, 287.

${ }^{84}$ Cited in Id., pp. 288, 289.
} 
most (if not all) of which have a much worse track record in dealing with ethnonational diversity". 85

\section{The Tension between Multi-ethnic Civic Identity and Article 39(1) of the FDRE Constitution}

Barrington discusses the confusion when the word 'nation' is interchangeably used with 'state' which represents "the principal political unit in the international political system corresponding to a territory, a relatively permanent population, and a set of ruling institutions". ${ }^{86} \mathrm{He}$ also states that it should not be misused as a word which is identical with the word 'country' because the latter is "the territorial component of the state". In short, the words nation, state and country respectively represent people, the political entity and territory.

Moreover, Barrington criticizes the loose definition of 'nation', a point that is very relevant to the current realities in Ethiopia:

The most basic loose use of 'nation' is the interchanging of the term and 'ethnic group' or 'ethnicity.' ... [N]ations can evolve from ethnic groups ... A nation is more than an ethnic group, differing from such a group because of a nation's belief in its right to territorial control, or what Richmond (1987) calls its 'territorial referent.' Also, and more important, nations need not even be based on a certain ethnic identity. Thus, the words 'shared cultural features' in the definition of nation ... should not be read as 'shared ethnic identity.' What are called 'civic' or 'political' nations in the nationalism literature have shared cultural features but are generally multiethnic in their make-up. .... ${ }^{87}$

The way forward envisages the enhancement of multi-ethnic civic identity among all Ethiopians based on citizenship. One of the factors that may hamper the progressive coalescence of multi-ethnic civic identity seems to be misconceptions about the constitutional 'right to secession' which can be manipulated by ethnic entrepreneurs. The political leadership that managed to have Article 39(1) ${ }^{88}$ inserted in the FDRE Constitution seemed to have been satisfied because the sub-article comes prior to other provisions that articulate the core normative principles on self determination, self-government, equality and fraternity. However, the drafting team has substantially watered down the

\footnotetext{
${ }^{85}$ Id., p. 289.

${ }^{86}$ Lowell W. Barrington (1997), "Nation" and "Nationalism": The Misuse of Key Concepts in Political Science, Political Science and Politics, Vol. 30, No. 4 (Dec., 1997), pp. 712716 Published by: American Political Science Association, p. 713.

${ }^{87}$ Ibid

${ }^{88}$ Article 39(1) reads: "Every Nation, Nationality and People of Ethiopia has an unconditional right to self-determination, including the right to secession."
} 
word 'unconditional' that is embodied in Article 39(1) by articulating procedures and the principles of equality, unity and fraternity.

Until constitutional amendments (such as revisiting Article 39/1) are undertaken, there is the need for clarity regarding its relationship with other provisions. Article 39(1) lays down the principle of the right to self determination which is unconditional and whose scope can extend up to secession. Article 39(2) articulates the elements of self determination with regard to language, culture and history. Article 39(3) ensures self-government and equitable representation in state and Federal governments, thereby assuring the rights to self-rule and shared-rule.

Article 39(4) stipulates the procedures under which the right to secession can come into effect, and it thus overrides the word 'unconditional' (in Article 39/1) in relation to session. The political objectives of these provisions are articulated in Article 88 which provides that:

1) "Guided by democratic principles, Government shall promote and support the People's self-rule at all levels".

2) "Government shall respect the identity of Nations, Nationalities and Peoples. Accordingly, Government shall have the duty to strengthen ties of equality, unity and fraternity among them".

The adverse impact of Article 39(1) of the FDRE Constitution relates to the perception it creates because it can be easily susceptible to political and economic elite capture thereby eroding beliefs and thoughts of multi-ethnic civic identity. Article 39(1) traces its roots to Joseph Stalin's views embodied in Article 72 of the USSR Constitution until the breakup of the Soviet Union during the early 1990s. It is to be noted that absence of such provision is not an absolute guarantee against attempts of secession (such as Biafra) and the actual occurrence of secession as in the case of South Sudan. The adverse impact of the provision does not thus mainly lie in its potential to be effectively invoked (in the near future), but in the misperception which it creates and the sense of shared citizenship and civic fraternity that it can gradually erode thereby causing challenges in the pace of nation building, economic development, social wellbeing and environmental sustainability.

Karen A. Cerulo cites Disraeli's observations which states that "[i]ndividuals may form communities, but institutions alone can create a nation", and she notes that "[e]qually important are a nation's symbols, rituals, and traditions" which constitute a nation's identity. ${ }^{89}$ These elements in nation building (including the institutions of trust, inter-ethnic fraternity and attachment to the national flag)

${ }^{89}$ Karen A. Cerulo (1993), 'Symbols and the World System: National Anthems and Flags', Sociological Forum, Vol. 8, No. 2, p. 243. 
are indeed crucial. This calls for addressing the tension between shared civic identity and the 'secession' clause in Article 39(1) of the FDRE Constitution.

It is thus high time to raise the question whether Ethiopia's Constitution which is currently the only constitution in the world that has a Stalinist provision (in the form of Article 39/1) - can (in light of Truth and Reason) be 'right' against the entire world. If the breakup of the former Soviet Union and Yugoslavia, and ethnic clashes in Ethiopia are not adequate enough to show us the path to Truth, Reason and Critical Thinking in this regard, we as a nationstate are too naïve to avoid institutional fragility (including justice sector institutions). Such oversight also negates the current trend toward sub-regional and regional integration in Africa via free trade areas and customs unions with the optimistic vision of Africa's ultimate political integration in 2063, i.e., a century from the formation of the Organization of African Unity in 1963.

\section{Legal Arguments regarding the Emblem on Ethiopia's Flag}

The clashes (on September $13^{\text {th }} 2018$, in Addis Ababa) over flags and emblems are incidences that indicate the need for clarity on the Ethiopian flag which represents Ethiopia's sovereignty. Attachment to a flag, inter alia, represents civic membership and commitment. Article 3 of the FDRE Constitution states the horizontal colours in the Ethiopian flag as "green at the top, yellow in the middle, and red at the bottom" that have equal dimensions. It also states that the flag "shall have a national emblem in the centre".

Article 3(2) provides that "the national emblem on the flag shall reflect the hope of the Nations, Nationalities, Peoples as well as religious communities of Ethiopia to live together in equality and unity". Article 3(3) recognizes the rights of members of the federation to have their respective flags determined by their respective legislatures. This provision does not, however, envisage flags of political parties. Of course, political parties have the right to design their emblems, but a flag that differs from the political party's emblem can be confused with flags that are only allowed at a country or regional state level.

There are issues that evoke controversy regarding the mandatory use of the emblem at the centre of the Ethiopian flag and the blue colour that is used as its background. There have been emblems during the previous regimes. However, it has never been unlawful for the public to use flags without emblems, even though flags with emblems were hoisted in key public offices and at the flag posts of some government institutions.

According to Article 3(1) of the FDRE Constitution, the national emblem shall be at the centre. This provision can imply the interpretation that the national emblem shall not go beyond the colour at the centre, i.e. the yellow colour. For example, among Pan-African flags that use green, golden and red (inspired by the Ethiopian flag), Cameroon, Ghana and Senegal use stars as 
emblems at the centre. However, the emblems use the colour at the centre as background, and they do not stretch to the upper and lower colours of the flag.

One can interrogate the constitutionality of the Flag Proclamation No. 654/2009 on two grounds. First, it introduces a fourth blue colour as background to the national emblem, and secondly, it violates the notion of 'centre' envisaged in the Constitution because it provides that the circumference of the blue colour is "curved on the midpoint of the width of both the green and red colours". 90

Article 3(1) of the Constitution envisages only three colours (green, yellow and red) and the emblem at the centre should have used the yellow in the centre as its background, by using green and/or red for drawing the star and rays. It can thus be argued that Article 6 of the Flag Proclamation is unconstitutional because it introduces a fourth colour to the Ethiopian flag. The fourth colour was initially introduced by the Flag and Emblem Proclamation No. 16/1996. The Proclamation clearly considered the blue as a fourth colour, and gave it a numerical sequence under Article 4. The provision titled "Meaning of the Colours of the Flag" reads:

"The colours of the Flag shall represent the following meanings:

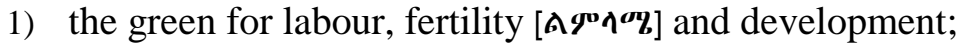

2) the yellow for hope, justice and equality; and

3) the red for sacrifice and heroism towards the prevalence of freedom and equality.

4) The circular blue background of the Emblem signifies peace."

The circular blue colour that serves as background does not add meaning because 'peace' is inseparable from justice, freedom and equality that are already represented by the other colours. The blue colour also disrupts the horizontal equal dimensions stated in Article 3(1) of the Constitution. Even worse, the background blue colour (which had slightly touched the green and red colours under Proclamation No. 16/1996) was enlarged after the enactment of the Flag and Emblem (Amendment) Proclamation No. 48/1996 (so that it could extend to the midpoint of the green and red colours). This enlarged background is adopted in Proclamation No. 654/2009. One can thus argue that Proclamation No. 654/2009 is unconstitutional because, it unduly allows a fourth colour, and the blue circular background disturbs the horizontal alignment and equal dimensions of green, yellow and red (thereby reducing the area of the yellow colour in the flag which represents hope, justice and equality).

\footnotetext{
${ }^{90}$ Article 6(1) of the Flag Proclamation No, 654/2009
} 


\section{Land Tenure Security and the Need to Avoid Role Conflict in Municipalities}

The problem related to equity in the economy (social injustice) is one of the factors for public dissatisfaction. This is very relevant in justice system institution building and broad-based economic and social empowerment. It is awkward that Ethiopia (as a primarily rural smallholder farmer economy) turns a deaf-ear to the volumes of academic literature on rural and urban land tenure security that can enhance economic efficiency, social wellbeing and environmental sustainability. For example, the scheme of land readjustment ${ }^{91}$ accommodates urban redevelopment or urban expansion without evicting urban or peri-urban landholders because the landholdings can be contributed as stock (share) in new investments to the mutual benefit of all parties, i.e. former landholders and investors.

Analogous to Article 39(1) of the FDRE Constitution (highlighted in the preceding section), 'government-ownership' of land in the Ethiopian land law regime is unique and contradicts with all legal regimes in the world. There is no land law throughout the world which states that land belongs to the 'government' 92 even though various countries consider land as state (or public) owned without, however, denying the tenure security of landholders. Even China, that has not yet set aside various communist party policies, recognizes the land use ownership rights of landholders (since 2007) while land ownership is in principle held by the state. ${ }^{93}$ In China, rights of landholders are transferable via sale, lease, or as stock contribution without the need for pretention and simulation. In Ethiopia, on the other hand, we are fully aware that a 'house' will be demolished by a buyer, and we pretend as if it is the house and not the land that is being sold.

Ethiopia's land regime is also inconsistent with the 'land to the tiller' slogan of the student movement of the 1960s and early 1970s. This motto did not envisage a setting which de facto relegates landholders to the position of

${ }^{91}$ See for example, Achamyeleh Gashu Adam (2015). "Land readjustment as an alternative land development tool for peri-urban areas of Ethiopia", Property Management, Vol. 33 Issues 1 (pp. 36 - 58): https://doi.org/10.1108/PM-05-2013-0034

See also, Kauko Viitanen et al (2010). Editor: Stig Enemark, Hanoi Declaration on Land Acquisition in Emerging Economies, International Federation of Surveyors (FIG), FIG Publication No. 51. February 2010

${ }^{92} \mathrm{See}$, for example, Article 5(6) of the Land Administration and Use Proclamation No. $456 / 2005$ which reads "Government being the owner of rural land, communal rural land holdings can be changed to private holdings as may be necessary".

93 See, Stebek (2015), 'Access to Urban Land and its Role in Enhancing Business Environment: Multi-track versus Mono-route Land-use Markets', Mizan Law Review, Vol. 9, No. 1 (September 2015), section 7, pp, 23-28: http://dx.doi.org/10.4314/mlr.v9i1.1 
disempowered tenants of the government without tenure security whenever the government invokes 'public purpose"94 even when it seeks to evict landholders and allocate their land to 'investors'.

The proclamations that consider land as 'government-owned' are unconstitutional because Article 40(3) of the FDRE Constitution confers land ownership on the state, nations, nationalities and peoples thereby implying joint ownership. At individual level, a rural or urban landholder (is an individual member of a nation, people, etc) and is, in effect, joint owner and not a mere holder who can be arbitrarily evicted. Analogous to an apartment in a condominium, an individual holder of urban or rural land can (under Article $40 / 3$ of the Constitution) be entitled to joint right in rem (right over the land), and exclusive right in rem over the physical property on the land.

The social movements that started at Ginchi in 2015 and the second wave of protests against evictions due to the new 'master plan' of Addis Ababa were the immediate causes of the civil disobedience that eventually led to the political reforms that are underway. This injustice of land tenure insecurity at the grassroots indeed deserves due attention on both grounds of equity and economic efficiency. Unfortunately, however, political parties, including the ruling party have not yet included the land tenure security agenda among their urgent concerns. Tenure security is related with the basic needs of people at the grassroots, i.e. daily engagement of citizens in meaningful economic activities and social services, decent meal, clean water, housing, health and education. Decent meal for most citizens at the grassroots, for example, is unimaginable in the absence of one of the core factors of production, i.e. stronger land tenure security which is a precondition for productivity, social wellbeing and environmental sustainability.

Economic and political elites in predatory states benefit from resource capture in the context of grass-root disempowerment. In business as usual scenarios, municipalities throughout Ethiopia will continue to be land lease 'boutiques' rather than municipal service providers (including uninterrupted water and power supply) thereby entering into an apparent role conflict between revenue generation (by leasing out as much urban space as possible) which clearly contradicts with the proper conduct of their municipal services. For example, the level of deterioration in municipal services in Addis Ababa with regard to water supply shortages, power outages, gaps in waste management, etc., clearly show the impact of the role conflict. We should have been able to

\footnotetext{
${ }^{94}$ On the need to redefine 'public purpose', for the purpose of expropriation, see, Muradu Abdo (2015), 'Reforming Ethiopia's Expropriation Law', Mizan Law Review, Vol. 9, No. 2 (December 2015), 301-340: http://dx.doi.org/10.4314/mlr.v9i2.3
} 
evaluate the performance of municipalities based on their municipal functions rather than their annual revenue from land lease. This is another feature of Ethiopia's unique malpractice (as opposed to all municipalities in the world).

A Municipality which is the custodian of a Master Plan and municipal functions cannot be entrusted with the opposite task of raising its lease-sale revenue through the sale of urban land through 'lease'. ${ }^{95}$ As the practice shows, cohorts of office holders in municipal land administrations face series of corruption charges, and again identical incidences of corruption and arrests repeat themselves in many parts of Ethiopia. Municipalities should thus be restricted to their conventional function of municipal services and the implementation of master plans; and another public authority not accountable to municipalities should be entrusted with land banking and acquisition based on master plans and with due respect to tenure security of landholders.

\section{The Need for Normative Gate Keeping against Predatory Statehood}

Although discontent and social movements have led to failed statehood in Libya and other countries, this has not been the case in Ethiopia -after three years of social movements since 2015- even though the risks of polarized fragmentation were graver. This antidote against failed statehood can only be sustained, inter alia, through rule of law which is, inter alia, characterized by public trust in all government organs, including the justice sector.

The ruling party claimed to pursue democratic developmental statehood after the 2005 elections. On the contrary, however, Ethiopia's politico-economic realities "were closer to predatory rather than developmental statehood because state intervention in democratic developmental states such as Botswana, targets at empowering (and not repressing and substituting) broad-based private sector". 96

A case in point regarding predatory acts in the Ethiopian context includes economic resource grabs by office holders under the façade of various frontpersons (who cannot explain their windfall 'wealth'). The acts of corrupt office

\footnotetext{
${ }^{95}$ See, for example, Stebek (2013), 'Role Conflict between Land Allocation and Municipal Functions in Addis Ababa', Mizan Law Review, Vol. 7, No. 2 (December 2013), 241-282: http://dx.doi.org/10.4314/mlr.v7i2.3

${ }^{96}$ For the contrast between developmental state versus predatory state interventions, see Section 4 titled "Comparative Experience in State Intervention toward Private Sector Empowerment -versus- Predatory Interventions (pages 45-50)" in Stebek (2017), 'Deliverables and Pledges under Ethiopian Trade Competition Law: The Need for Private Sector Empowerment and Enablement", Mizan Law Review, Volume 11, No. 1 (September 2017), pp. 32-63. DOI: http://dx.doi.org/10.4314/mlr.v11i1.2
} 
holders and a significant portion of the economic elite also include contraband trade chains that have considerably displaced the taxpaying private sector. The endpoint of this chain is clearly visible in the magnitude of street vending in cities such as Addis Ababa. Such corruption and claims of phony legitimacy (though elections) cannot thrive in settings where justice sector organs are empowered and independent. Thus, interventions in the mandates and operations of justice sector institutions become inevitable in predatory states.

As Eun Mee Kim observes, predatory states use their power "for capricious extraction and wasteful consumption" and this "diminishes private productive capacities rather than enhancing them" as a result of which welfare and growth suffer. ${ }^{97}$ Vaughan and Gebremichael also noted that developmental patrimonialism succeeds only when the pot (oqde) grows and ensures a "reasonably sustainable access to it", in the absence of which "a transition economy of low productivity, poorly co-coordinated markets, opportunistic rents, unregulated entrepreneurialism has frequently led to non-developmental kleptocracy". 98

The economic policies in Ethiopia were indeed susceptible to predatory statehood which creates and nurtures elites of oligarchs rather than a broader middle class. While few individuals form the political stratum and economic elites usually become predators in such settings, the economy at large and the population are prey to their predators. In the Ethiopian context, predatory interventions include rigidity against land reform because the political and economic elites have vested interest in land acquisitions in the guise of 'land lease' and 'investments'. Insecure landholding also meant a carrot and a stick tool in controlling voter behaviour and small-scale enterprise support schemes.

Oligarchs 'benefit' from reflexive 'growth' in predatory states whose eclectic policies and decisions are characterized by whims and haphazard pursuits. Under such settings, elegant formulae of 'economic growth', glittering powerpoint presentations and fake reports (rather than the reality on the ground) prompt policy decisions. In the context of non-inclusive oligarchy, reflexive decisions have, inter alia, brought about waves of haphazard high-rise constructions in Addis Ababa and other cities, excessive foreign debt, currency printouts unmatched by the production of goods and services, imprudent projects, and levying of Value Added Tax (VAT) on basic goods including food

${ }^{97}$ Eun Mee Kim (1993), "Contradictions and Limits of a Developmental State: With Illustrations from the South Korean Case" Social Problems, Vol. 40, No. 2 (May, 1993) p. 247.

${ }^{98}$ Sarah Vaughan and Mesfin Gebrehiwot (2011), 'Rethinking business and politics in Ethiopia The role of EFFORT, the Endowment Fund for the Rehabilitation of Tigray', Africa Power and Politics, Research Report 02, August 2011p. 60. 
(to make up for excessive government expenditures). As Tekle-Birhan GebreMichael duly observes:

The infrastructure development through currency printing, foreign debt and foreign aid has little contribution to production, and has thus entailed inflation, fall in the exchange rate of Birr, foreign currency shortages, corruption and waste of resources. ${ }^{99}$

The reversal of predatory statehood and reflexive 'growth' calls for rule of law and substantial reform of justice sector institutions (including the land law regime). As the justice sector operates within the economic, social and political realities of Ethiopia, any positive development in these sectors toward sustainable development and democratization inevitably facilitates justice sector reform owing to their dialectical and bi-directional causal relationship.

\section{Concluding Remarks}

Justice system reform and laws (that constitute rational expressions of the 'general will' rather than a political party manifesto) are among the factors that determine the pace of Ethiopia's overall institutional development. Challenges such as the themes discussed in the preceding sections, i.e. institutional discontinuity, ethnic politics and the land law regime illustrate root causes of problems that render justice system reform difficult.

It is indeed commendable that the revision of Ethiopia's laws in areas such as anti-terrorism and civil societies is given due attention. There are also other areas that need due focus in addition to the ones that have received priority. They include a legal regime on stock market (in the absence of which pledges of privatization of Ethio-telecom, Ethiopian Airlines, Commercial Bank of Ethiopia, etc would merely entrench oligarchy), due attention to quality and standards in education, language policy and Population-Health-Environment (PHE) nexus policy. It is to be noted that the quality and standards of education and due attention to value systems and moral character (such as work ethic) are foundations for every pursuit in nation building, sustainable development, social wellbeing and progress.

Other areas that call for reforms include meritocratic (as opposed to political party-affiliated) assignments in the public service and the levels of remuneration (including the justice sector), the pace of march toward multi-ethnic political party programs, caveats against laissez faire hedonism (such as the tchat/khat

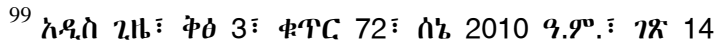

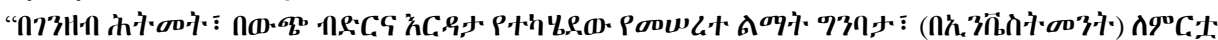

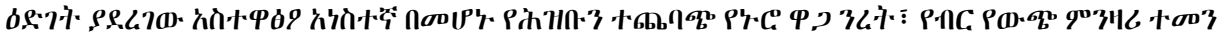
oоd.
} 
wave), autonomy of the National Bank of Ethiopia (so that monetary policy including the volume of paper money in circulation can be determined by NBE with due professionalism and independence), the need for transferring constitutional interpretation to courts, reinstatement of shares in private banks that were owned by the diaspora, ${ }^{100}$ and many others which have been issues of discourse in various research works. These issues can be incrementally and progressively addressed because they have been themes of academic discourse.

There is no dearth of literature with regard to these and many other pertinent issues as long as prime attention is given to critical inquiry, Truth and Reason. As one of the external assessors of this article duly observed:

The question of 'who owns and supports justice system reform initiatives in Ethiopia' is crucial. Is it the government on top? or, justice sector institutions, the general public, donors, the civil society including the legal profession? or all of these together? This is a critical question to ask while addressing the question as to why reforms have not been effective or sustainable. Some researches show that countries can be grouped into three when their legal and judicial reforms are assessed: (i) those where the politicians, legal professionals and the public support reforms, (ii) those where politicians support reforms, but lawyers, the public and other law enforcement organs do not; and (iii) those where only the legal professions want reforms but not the politicians. Only reforms of the first category can attain their objectives. .. ${ }^{101}$

The participation of law professionals in the law reform process and the level of political will are commendable with regard to the efforts and achievements of the Legal and Justice Affairs Advisory Council (highlighted in Section 2.1). However, this cannot be sustainable unless the activities, task processes and achievements of the Council are well-documented and institutionalized thereby leading to entities such as Law Reform Commission (or Law Commission) with a view to sustaining and enhancing institutional memory, institutional continuity, professionalism and public engagement in law reform.

Moreover, mere expression of JLRTI's mandate under Proclamation No. 1071/2018 cannot ensure its effective performance in the absence of the legal profession's active engagement. The construction of premises to JLRTI at the peripheral outskirts of Addis Ababa -that are not easily accessible- does not facilitate such integrated engagements. A few offices at a proximate location

\footnotetext{
${ }^{100}$ See, for example, Tameru Wondim Agegnehu (2017), 'Legal Issues regarding the NBE Guideline on Diaspora-Owned Shares in Banks', Mizan Law Review, Volume 11, No. 2 , December 2017, http://dx.doi.org/10.4314/mlr.v11i2.6

${ }^{101}$ Second reviewer's comments.
} 
that are convenient to JLRTI staff and easily accessible to the legal profession are far better than buildings and a spacious compound in the outskirts of the city that require hours of transport -while such precious time could be devoted to effective research. The newly constructed premises can thus be assigned to Justice Organ Professionals Training Centre (JOPTC) which can focus on judicial training under the Federal Supreme Court. This author argues that JOPTC (whose function is to, inter alia, conduct judicial training) cannot be part of JLRTI as the latter is under the Attorney General's Office in accordance with Proclamation No. 1097/2018.

The way forward requires political will in addressing the root causes for the regression of Ethiopia's justice system, and it further calls for joint efforts of all stakeholders including the legal profession and the public. In the course of pragmatic initiatives and pursuits, the unattained elements among the 2002 and 2005 justice system reform recommendations can indeed be utilized (with some updating by the respective institutions as shown in Section 2.2) because they are a fortiori relevant today than they were during their formulation.

As Hodgson notes, institutions are "systems of established and prevalent social rules that structure social interactions". ${ }^{102}$ These systems envisage a blend of organic and consciously formulated norms, structures and modes of operation. Reflexive and haphazard institutional reforms cannot thus succeed since institution building (including justice system reform) envisages roadmap clarity and because a wrong path does not lead to intended destinations.

However, policy roadmaps in Ethiopia have been blurred and inconsistent. A query that arises is the extent to which policies are informed by particular tracks in the constitutional democracy landscape from social democracy to liberal market economy (with due caveat against extremist neo-liberal de-regulation). ${ }^{103}$ To borrow some words from Lewis Caroll's famous quote, "[if we] don't know where [we] are going, any road will get [us] there." ${ }^{104}$ In the context of the justice sector, piecemeal and reflexive trial and error, which is not based on a proactive strategic roadmap (with due synergy among justice sector institutions) would only pull the justice system to the unknown, and in effect, to further regression.

${ }^{102}$ Geoffrey M. Hodgson (2006). "What are Institutions?” Journal of Economic Issues, 40(1), p. 2.

${ }^{103}$ The words 'neo-liberal' and 'developmental state' were usually misdefined in official statements since 2005/2006. Criticisms against predatory features of the ruling party's interventions were unduly labelled as 'neo-liberal'. However, neo-liberalism refers to extreme de-regulatory prescriptions such as the 'Washington Consensus' of the late 1980s.

104 "If you don't know where you are going, any road will get you there." (Charles Lutwidge Dodgson, 1832-1898, known by his pen name Lewis Caroll). 